\title{
Work-related learning and skill development in Europe: Does initial skill mismatch matter?
}

Citation for published version (APA):

Ferreira Sequeda, M., Künn, A., \& de Grip, A. (2016). Work-related learning and skill development in Europe: Does initial skill mismatch matter? ROA. ROA Research Memoranda No. 009 https://doi.org/10.26481/umaror.2016009

Document status and date:

Published: 01/01/2016

DOI:

10.26481/umaror.2016009

Document Version:

Publisher's PDF, also known as Version of record

\section{Please check the document version of this publication:}

- A submitted manuscript is the version of the article upon submission and before peer-review. There can be important differences between the submitted version and the official published version of record.

People interested in the research are advised to contact the author for the final version of the publication, or visit the DOI to the publisher's website.

- The final author version and the galley proof are versions of the publication after peer review.

- The final published version features the final layout of the paper including the volume, issue and page numbers.

Link to publication

\footnotetext{
General rights rights.

- You may freely distribute the URL identifying the publication in the public portal. please follow below link for the End User Agreement:

www.umlib.nl/taverne-license

Take down policy

If you believe that this document breaches copyright please contact us at:

repository@maastrichtuniversity.nl

providing details and we will investigate your claim.
}

Copyright and moral rights for the publications made accessible in the public portal are retained by the authors and/or other copyright owners and it is a condition of accessing publications that users recognise and abide by the legal requirements associated with these

- Users may download and print one copy of any publication from the public portal for the purpose of private study or research.

- You may not further distribute the material or use it for any profit-making activity or commercial gain

If the publication is distributed under the terms of Article $25 \mathrm{fa}$ of the Dutch Copyright Act, indicated by the "Taverne" license above, 


\section{Work-related learning and skill development in Europe: \\ Does initial skill mismatch matter?}

Maria Ferreira

Annemarie Künn-Nelen

Andries de Grip

\section{ROA Research Memorandum}

ROA-RM-2016/9

Researchcentrum voor Onderwijs en Arbeidsmarkt | ROA Research Centre for Education and the Labour Market | ROA 


\title{
Work-related learning and skill development in Europe: Does initial skill mismatch matter?
}

\author{
Maria Ferreira \\ Annemarie Künn-Nelen \\ Andries de Grip
}

ROA-RM-2016/9*

September 2016

Research Centre for Education and the Labour Market

Maastricht University

P.O. Box 616, 6200 MD Maastricht, The Netherlands

$\mathrm{T}+31433883647 \mathrm{~F}+31433884914$

secretary-roa-sbe@maastrichtuniversity.nl

www.roa.nl

\footnotetext{
* The ROA Research Memorandum Series was created in order to make research results available for discussion, before those results are submitted for publication in journals.
} 


\section{Abstract \\ Work-related learning and skill development in Europe: Does initial skill mismatch matter?**}

This paper provides more insight into the relevance of the assumption of human capital theory that the productivity of job-related training is driven by the improvement of workers' skills. We analyse the extent to which training and informal learning on the job are related to employee skill development and consider the heterogeneity of this relationship with respect to workers' skill mismatch at job entry. Using data from the 2014 European Skills Survey, we find - as assumed by human capital theory - that employees who participated in training or informal learning show greater improvement of their skills than those who did not. The contribution of informal learning to employee skill development appears to be larger than that of training participation. Nevertheless, both forms of learning are shown to be complementary. This complementarity between training and informal learning is related to a significant additional improvement of workers' skills. The skill development of workers who were initially underskilled for their job seems to benefit the most from both training and informal learning, whereas the skill development of those who were initially overskilled benefits the least. Work-related learning investments in the latter group seem to be more functional in offsetting skill depreciation than in fostering skill accumulation.

JEL classification: J24, M53

Keywords: training, informal learning, skill development, skill mismatch, human capital

Maria Ferreira

Maastricht University

ROA

P.O. Box 616

NL-6200 MD Maastricht

The Netherlands

m.ferreirasequeda@maastrichtuniversity.nl

and Industrial University of Santander,

Colombia

Andries de Grip

Maastricht University

ROA

P.O. Box 616

NL-6200 MD Maastricht

The Netherlands

a.degrip@maastrichtuniversity.nl

and IZA, Bonn
Annemarie Künn-Nelen

Maastricht University

ROA

P.O. Box 616

NL-6200 MD Maastricht

The Netherlands

a.kuenn@maastrichtuniversity.nl

and IZA, Bonn

\footnotetext{
** We gratefully acknowledge comments from Jim Allen, Zafer Büyükkececi, Sara de la Rica, Rolf van der Velden, and participants at the Cedefop/IZA Workshop on Skills and Skill Mismatch (2015); the Workshop on Education, Skills, and Labor Market Outcomes (2016); and the ESPE conference (2016).
} 


\section{INTRODUCTION}

To deal with the challenges of rising global competition, the European Union has set itself goals with respect to formal training and informal learning in the workplace to 'acquire and develop new skills throughout the lifetime of individuals' and increase their productivity (European Commission 2010:16). This idea that lifelong learning improves workers' skills builds on human capital theory (Mincer, 1962; Becker 1964; Ben-Porath, 1967; Heckman, 1976). Several empirical studies have shown that job-related training is associated with higher wages and productivity (e.g. Acemoglu \& Pischke, 1999; Blundel et al., 1999; Leuven \& Oosterbeek, 2008; Görlitz, 2011). However, due to lack of data on skill development, there is hardly any empirical literature on the contribution of different forms of human capital investments to workers' skill development.

In this paper, we provide more insights into the relevance of the assumption that the productivity of training is driven by the improvement of workers' skills. We analyse the extent to which work-related learning is related to the skill development of workers in 28 European countries. We thereby distinguish between formal training participation and informal learning on the job and examine whether the substitution or complementarity between these two types of learning plays a role in workers' skill accumulation. To better understand these relationships, we allow for heterogeneity with regard to employee skill mismatch at job entry. ${ }^{1}$

The 2014 European Skills Survey shows that, at the start of a job, a significant proportion of the labour force in Europe has skills that either exceed the demands of their job or are insufficient for adequate job performance: 24 percent of all workers report that some of their skills were initially lower than what was required in their job, whereas 25 percent report that their skills were initially higher than required. In comparison with well-matched workers, those who are underskilled, on the one hand, probably need more training or informal learning on the job to perform at an adequate level. We therefore expect job-related learning to add more to these workers' skill level. On the other hand, workers who are overskilled could be more likely to have other reasons to engage in job-related learning, such as keeping their skills up-to-date, which might not reveal skill improvement as such. Because of these differences in the degree of workers' skill utilisation on the job and in the underlying reasons for participating in job-related learning, the skill development of initially mismatched workers is expected to differ from that of workers whose skills fully matched the skill demands in their job.

For this study, we use data on more than 37,000 employees from the European Skills Survey, conducted in 2014 by the European Centre for the Development of Vocational Training (Cedefop). This survey is one of the first in which different types of job-related learning as well as employees' skill development and mismatch are measured. Although these data are not sufficient to establish causality, we provide relevant empirical evidence on the expected relationship between different forms of workplace learning and employee skill accumulation, which has, until now, been a black box in the

\footnotetext{
${ }^{1}$ Since workers' skill mismatch could improve when they participate in learning, we use information on individuals' skill mismatch at the start of the job with their current employer rather than their current skill mismatch status. Hereafter, we use the terms underskilled, well matched, and overskilled to refer to the skill mismatch status of employees at job entry.
} 
empirical human capital literature that has mainly focused on workers' wages (De Grip \& Sauermann, 2013).

Our study contributes to the literature in three more ways. First, whereas most empirical studies focus on training participation, we are able to differentiate between formal training and informal learning to investigate in more detail the extent to which workers' participation in different forms of work-related learning contributes in the improvement of their skill levels. Second, we provide more insights into the complementarity between training and informal learning on the job by analysing their interaction in the development of workers' skills. Third, we examine the heterogeneity of the relationships between training and informal learning and workers' skill development with respect to the initial job-worker mismatch status.

In line with the hypotheses derived from skills production models, we find that employees who participate in training or who are more often involved in informal learning show greater skill improvement. The relationship between informal learning on the job and employees' skill development appears to be stronger than that between training participation and skill development. Nonetheless, there is complementarity between these two forms of work-related learning. This complementarity seems to favour skill development since we find that workers who participated in both training and informal learning show significant additional improvement of their skills. This finding is consistent with the notions of the complementarity and cross-productivity of human capital (Cunha \& Heckman, 2007) in an on-the-job context. We also find that skill mismatches induce heterogeneities and moderate the previous outcomes. Thereby, we find that well-matched, underskilled, and overskilled employees differ in the extent to which investments in training and informal learning - and their complementarity - are associated with the accumulation of their skills during their working life. A stronger relationship between work-related learning and skill development suggests that initially underskilled employees benefit the most from both training and informal learning, whereas overskilled employees benefit the least. Human capital investments in the latter group seem to be more functional in counteracting skill depreciation and maintaining their skill level than in fostering skill accumulation, as suggested by literature on skill obsolescence (e.g. De Grip \& van Loo, 2002). Our study then suggests that being employed in a skill-challenging job or a job that underutilises a worker's skills has important implications on the returns to investment in both training and informal learning.

We also analyse the contribution of different types of training and informal learning to workers' skill development. We find that, among well-matched and underskilled employees, training during working hours and training paid by the employer are more strongly related to workers' skill development than training outside working hours and training paid by the employee. Among overskilled workers, however, these differences are rather small and statistically insignificant. With respect to informal learning, we find that, for workers in well-matching jobs, informal learning from colleagues and supervisors seem to contribute to their skills as much as informal learning by trial and 
error and self-study. Underskilled workers, however, show greater skill improvement when learning by self-study. In contrast, overskilled workers seem to benefit more from informal learning by trial and error and learning from colleagues and supervisors than from self-study, which appears to be insignificant for their skill improvement.

The remainder of the paper is structured as follows. Section 2 discusses the relevant literature. Section 3 describes the dataset and the definitions of skill development and skill mismatch as well as the other variables used in the analyses. Section 4 describes the estimation method we use - ordered probit models with interaction effects - and explains how to interpret the results. The results are presented in Section 5. Section 6 concludes the paper.

\section{LITERATURE}

\subsection{Human Capital Investments and Skill Development}

Human capital theory considers on-the-job learning an investment that increases workers' productivity and wages via the accumulation of skills (Mincer, 1962; Ben-Porath, 1967; Becker 1964; Heckman, 1976). First, at the individual level, most of the empirical literature deals with the relation between training and wages, since hard measures of individual productivity are rare (Acemoglu \& Pischke, 1999; Blundel et al., 1999; Leuven \& Oosterbeek, 2008; Görlitz, 2011; O’Connell \& Byrne, 2012). An exception is the study of De Grip and Sauermann (2012), who assess the effects of job-related training on individual performance by means of a field experiment. Second, at the firm level, most studies focus on the relation between average training participation and firm productivity as measured by value added (Bartel, 1994, 2000; Lowenstein \& Spletzer, 1998; Barrett \& O'Connell, 2001; Dearden et al., 2006; Sepulveda, 2010). However, due to lack of data, the empirical question whether training and informal learning affect workers' performance by increasing workers' skills or whether the performance increase is attributable to other factors still remains (De Grip \& Sauermann, 2013).

There is one exception. Green et al. (2001) analyse training on and off the job as a determinant of skills supply. Using the British Skills Survey, the authors find that off-the-job training is a determinant of all types of skills included in their analysis except team working, whereas on-the-job training contributes only to workers' problem-solving and team-working skills. However, Green et al. (2001) measure tasks rather than skills by using information on the importance of workers' particular job activities as the dependent variable. Furthermore, their skills measure refers only to one point in time, which does not allow for analysing workers' skill development over time. Moreover, due to lack of data, the authors cannot explore the contribution of informal learning to skill formation.

One of the main tenets of our paper is that the skills individuals can accumulate by learning on the job are acquired not only by formal training but also by informal learning. Early support for this idea can be found in Mincer (1974), who claimed that on-the-job informal learning probably constitutes the essential part and the major human capital investment in the workplace. Empirical studies such as those of Levitt et al. (2012) and Destré et al. (2008) have, respectively, shown that 
learning by doing and learning from others are significantly important in explaining workers' earnings and firm productivity. However, due to data limitations and the assumption in standard models that experience absorbs the work-related learning effect, there is hardly any empirical evidence that informal learning on the job is positively related to workers' skill improvement or productivity.

Last but not least, human capital literature indicates that there could be direct complementarity and cross-productivity (Carneiro \& Heckman, 2003; Cunha \& Heckman, 2007) between training and informal learning investments in the workplace. If training participation encourages informal learning and vice versa, investments in one type of learning could raise the marginal productivity of investments in the other type, in terms of skill accumulation. That is, skills acquired by training and informal learning could boost each other and thus further reinforce the skill development of workers who participate in both types of work-related learning. In our study, we explore the probability of such complementarity and cross-productivity of work-related training playing a part in the skill development of European employees. Hence, the availability of measures of training participation and informal learning as well as skill changes enables us, to some extent, to open the black box in the economic literature and provide additional insight into the transfer of lifelong learning to workers' skills (De Corte, 2003; De Grip \& Sauermann, 2013).

\subsection{Skill mismatch and Human Capital Investment}

Research on job mismatch concentrates mostly on the wage outcomes of overeducation (see Groot, 1996; Hartog, 2000; Chevalier, 2003; Di Pietro \& Urwin, 2006; McGuinness, 2006; Dolton \& Silles, 2008). More recently, the literature has exhibited a shift in emphasis from overeducation to skill mismatch (see Chevalier \& Lindley, 2009; McGuinness \& Wooden, 2009; O‘Leary et al., 2009; Green \& Zhu, 2010; Mavromaras et al., 2010; McGuinness \& Sloane, 2011; Mavromaras \& McGuinness, 2012; McGuinness \& Byrne, 2014). These studies have shown that overeducation and overskilling refer to different phenomena and that overeducation may not fully capture the extent to which an individual's skills are utilised at work. Educational attainment does not incorporate any measure of ability $^{2}$ or skills acquired through employment, while job entry requirements are imprecise at measuring a job's skill content. Measuring workers' skill mismatch could solve these difficulties by requiring individuals to compare the actual skills requirement of their job with their own skills acquired by either initial education, or training, or informal learning or related to their general ability.

On the one hand, the objective measure of educational mismatch seems statistically superior. However, apart from being rarely available at the necessary job level, these indicators rely on the symmetry in the distribution of required education along occupations, and have been shown to be rather poorly correlated with skill mismatches (Sloane et al. 1996; Allen \& van der Velden, 2001; Green \& McIntosh, 2007). On the other hand, self-reported measures of skill mismatch avoid the symmetry assumption and incorporate more than only formal education but rely on subjective

\footnotetext{
${ }^{2}$ It has been argued that overeducated workers are likely of lower ability and, therefore, the wage penalty could be largely explained by this unobserved heterogeneity (Groot, 1996; Sloane et al., 1999). This supports the idea that employers learn about the productive abilities of overeducated employees and pay them lower wages.
} 
assessments. Although susceptible to measurement error due to subjective bias, skill mismatch is still considered a more adequate and potentially more robust measure of skills underutilisation and overutilisation than educational mismatch is (Linsley, 2005; Mavromaras \& McGuinness, 2012).

The literature on educational and skill mismatches coexists with the empirical literature on wages and training; however, there has been little interaction between the two fields, despite the fact that on-the-job human capital investments could be a response to initial conditions of job-skill mismatch. Economic theory implies this connection in search and matching models in which training is considered a supplement to formal education in the way that it bridges the gap between generic skills acquired through schooling and specific skills required in the workplace (Acemoglu \& Pischke, 1999; Arulampalam et al., 2004). Consequently, training is expected to contribute to the adjustment between workers' potential productivity and the productivity ceiling of the job in which they are employed (Blazquez \& Jansen, 2008).

Models of skill formation have also underlined that, besides skill augmentation, training also plays a critical role in the restoration and replenishment of human capital in the context of skill depreciation (Rosen, 1975; Mincer \& Ofek, 1982). In this regard, empirical studies find that overeducated workers participate less often in training than those who are well matched, whereas undereducated workers participate more often (van Smoorenburg \& van der Velden, 2000; Messinis \& Olekalns, 2007). These studies have also found that training helps to close the gap between the actual and required education of undereducated workers through the acquisition of new skills and that training offsets the depreciation of the human capital of overeducated workers. Messinis and Olekalns (2008) find, moreover, that training participation relates to substantial wage benefits for undereducated workers in relation to their well-matched co-workers and enables overeducated employees to reduce the wage penalty associated with the mismatch. The authors also find that these wage returns to training are asymmetric, that is, the undereducated seem to benefit more than those with just the right education, while the overeducated benefit the least.

The question whether the relationship between work-related learning and workers' skill improvement differs by their initial mismatch status has not been analysed in the empirical literature. A mismatch between employees' skills and the level of their jobs could have important implications on skill returns to investment in both training and informal learning due to several reasons. In comparison with workers in a well-matching job, underskilled and overskilled workers likely have different aims when participating in job-related learning. The former probably need more training and learning to perform at an adequate level in such challenging jobs, whereas the latter may be more likely to invest in learning to keep their skills up-to-date or to counteract skill depreciation, which might not reveal skill improvement per se.

In this respect, our study relates to the literature on human capital depreciation, which has also explored the relation between skill mismatch and skill obsolescence. Building on the 'use it or lose it' hypothesis or the 'atrophy' of a worker's skills by non-use, this literature has shown that overqualified 
workers who are unable to fully utilise their skills in their job are less able to sustain their cognitive level and are, therefore, more vulnerable to experience skill decline (e.g. De Grip \& van Loo, 2002; De Grip et al., 2008).

If we integrate the preceding evidence on skill depreciation into the standard model of skill formation, ${ }^{3}$ the skill returns of further investments in training and informal learning are expected to vary with the workers' job-skill mismatch status. A key feature of the technology of skill development is that skills bolster each other over the life cycle because acquired skills raise both the level and productivity of subsequent learning investments in a multiplier process (Cunha \& Heckman, 2007). However, these attributes of human capital might be reduced if skills are underutilised in the job or increased if job skill demands are higher. Being underskilled at job entry could serve as a positive context, not only in raising the level of further learning investments but also in the effectiveness of these investments in human capital, given their initial stock of skills. Conversely, being overskilled at job entry could act as a negative context, not only because a worker's initial stock of skills may deteriorate due to non-use, but also because this deterioration may decrease the effectiveness and complementarity of further learning investments in the accumulation of human capital. This is consistent with Cunha and Heckman's (2007) evidence that higher initial stocks of human capital are not productive if they are not followed up by later investments over the life cycle.

This notion of the skill multiplier presented by Cunha and Heckman (2007) enable us to better understand the interaction between work-related human capital investments and the degree of on-thejob utilisation of the initial stock of workers' skills. In comparison with individuals whose acquired skills are appropriately used in their job, those with a higher initial stock of skills than required for their job are expected to have greater skill multiplier potential but, at the same time, lower levels of investment in training and informal learning on the job. According to the technology of skill formation, this implies a lower complementarity of human capital investments and, therefore, a lower marginal productivity of later investments. Conversely, underskilled workers are expected to have a lower skill multiplier potential because of their lower stock of skills compared to what is required in their jobs. These workers could, however, show greater investments in work-related training and informal learning to substitute for their lack of skills needed to perform at an adequate level in their job, which could produce stronger complementarity between human capital investments and hence a higher marginal productivity of later remedial investments in training and informal learning.

There is one more reason to expect that matched and mismatched workers differ in the extent to which their skill development and learning investments are related. The notion that worker motivation fosters a more efficient cognitive acquisition of skills suggests that, among overskilled workers, the productivity of training and learning on the job may be lower if they are generally less motivated and satisfied, as has been shown in the literature (e.g. Hersch, 1991; Verhaest \& Omey, 2009; Green \& Zhu, 2010). We build on the theoretical and empirical studies discussed above to

\footnotetext{
${ }^{3}$ Models on skill formation such as those in Killingsworth (1982), and Cunha and Heckman (2007) assume that skills acquired in one period persist into the future without any deterioration.
} 
explore in more detail the heterogeneity in the relationship between work-related learning and skill development with regard to employees' skill mismatch at job entry.

\section{DATA AND DESCRIPTIVE ANALYSES}

\subsection{Data and Sample}

We use data from the European Skills Survey, conducted in 2014 by Cedefop in 28 European countries. The survey was based on a representative sample of the working population aged 24-65 years in each of the participant countries and administered either online or by telephone to 48,676 individuals. ${ }^{4}$ The survey provides unique self-reported measures of employees' changes in skill accumulation as well as changes in skill mismatch over years of tenure with the same employer. Comparable measures are not available from any other large-scale dataset. Furthermore, this survey provides information on both the incidence of training and the intensity of informal learning in the workplace, in addition to other individual, job, and employer characteristics. ${ }^{5}$ We restrict our analyses to full-time employees, ${ }^{6}$ obtaining a sample of 37,285 individuals. Table A1 in the Appendix shows the sample distribution by country.

\subsection{Variables and Descriptive Analyses}

Table A2 in the Appendix shows the main descriptive statistics of the variables included in our analyses.

\subsubsection{Dependent Variable}

Our outcome variable, workers' skill development is based on self-assessed changes in skills ${ }^{7}$ since the start of their current job. It is derived from the following question: ${ }^{8}$

Compared to when you started your job with your current employer, would you say your skills have now improved, worsened, or stayed the same? Please use a scale of 0 to 10 , where 0 means your skills have worsened a lot, 5 means they have stayed the same, and 10 means they have improved a lot.

The mean reported skill development is 7.76, with a standard deviation of 1.77. As shown in Table 1, approximately 86 percent of the individuals in the sample reported that their skills had improved (scores of six to 10), whereas only 14 percent indicated that their skills had stayed the same (score of five) or worsened (scores of one to four).

\section{[Insert Table 1 about here]}

\footnotetext{
${ }^{4}$ See Ipsos MORI (2014) for further details about data validation.

${ }^{5}$ This dataset has, however, some limitations for our analyses, which we discuss in Section 5.1.2 when performing robustness checks of our main results.

${ }^{6} \mathrm{We}$ consider those who reported a minimum of 35 working hours a week full-time employees.

${ }^{7}$ Skills were defined in the questionnaire as 'all of the knowledge, abilities, and competences that you have gained as part of your education and also during the time you have been working'.

${ }^{8}$ The response rate to this question was 98 percent; only 2 percent of employees stated they had current skills not comparable to those they had before or did not to know the answer to the question.
} 


\subsubsection{Explanatory variables}

First, we distinguish between two types of work-related learning: training and informal learning.

- The variable Training is a dummy variable that takes the value one if the employee has participated in training courses since the start of the current job and zero otherwise. It is based on the question, 'Since you started your job with your current employer, have you attended training courses (workbased, classroom-based, and online)?' Since this question was only asked to those who reported having experienced positive skill development, we use the response to the question on training participation in the last 12 months for those whose skill declined. ${ }^{9}$ Table A2 of the Appendix shows that 62 percent of all employees in our sample participated in training courses at least once since they started their current job, while 57 percent did so during the last 12 months. Among the latter, we observe that 45 percent underwent their training mainly during working hours, while 22 percent did so outside working hours. For 69 percent of the workers, training was fully financed by the employer, whereas 12 percent financed it themselves. As shown in Figure 1, the density distribution of employees' development of skills shifts to the right when workers participate in training. We also observe this significant difference in the mean value of the variable for skill development by training participation, which is 8.40 for training participants and 7.07 for non-participants. This already indicates a positive relation between training participation and skill development.

\section{[Insert Figure 1 about here]}

- Informal learning is measured by a categorical variable $I L$ derived from the question 'How often, if at all, does your job involve learning new things?' The respondent's options were 'never', 'sometimes', 'usually', or 'always'. Table A2 of the Appendix shows that 55 percent of all the employees in our sample stated that they usually or always learned informally on the job, whereas only 4 percent said they were never involved in learning at work. Importantly, as shown in Figure 2, the density distribution of skill improvement is more concentrated to the right when workers are more often involved in informal learning. Accordingly, the mean value of the variable skill development also varies with the frequency of informal learning on the job. These values are 8.35 and 6.69 for workers who stated that they were always and never involved in informal learning while working, respectively. This provides first evidence that informal learning is also positively related to workers' skill development. In additional analyses, we differentiate between three types of informal learning by including dummy variables for 1) learning from colleagues and supervisors, 2) learning by trial and error, and 3) learning from self-study. ${ }^{10}$

\section{[Insert Figure 2 about here]}

\footnotetext{
${ }^{9}$ Training participation since the start of the job and during the last 12 months are highly positively correlated (0.67). A total of 81 percent of workers who answered both questions on training participation since job entry and during the last 12 months gave the same answer to both questions.

${ }^{10}$ These variables are based on the question 'Since you started your job with your current employer, have you done any of the following...?' Respondents could indicate as many of the following answers as applicable: 'a) your supervisor taught you on-the-job, b) you learned by interacting with colleagues at work, c) you learned at work through trial and error, and d) you learned by yourself (e.g. with the aid of manuals, books, videos or on-line materials)'.
} 
Second, we distinguish between workers who experienced a mismatch at the start of their current job and those who did not.

- Initial job-skill mismatch status is a categorical variable that takes three different values (initially well matched, initially underskilled, initially overskilled) corresponding to the three possible responses to the following question:

When you started your job with your current employer, overall, how would you best describe your skills in relation to what was required to do your job at that time? a) my skills were matched to what was required by my job, b) some of my skills were lower than what was required by my job and needed to be further developed), or c) my skills were higher than required by my job.

In our sample, 51 percent of all the employees stated they had a good skills match at the start of their jobs, while 24 percent considered themselves initially underskilled and 25 percent considered themselves initially overskilled. As shown in Figure 3, the distribution of skill development differs between the three different groups in favour of employees who were initially underskilled. We also observe significant differences in the mean value of the variable for skill development by skill mismatch status, which is 7.78 for the well matched, 8.41 for the underskilled, and 7.15 for the overskilled. This descriptive evidence suggests that workers who start a job with fewer skills than required make the largest skills progress when gaining years of tenure.

\section{[Insert Figure 3 about here]}

Table A2 shows other differences between initially underskilled and overskilled workers. For those who were initially overskilled, a slightly higher proportion is male and higher educated. Moreover, these workers more often have temporary contracts and fewer years of tenure. Furthermore, the table shows a higher percentage of underskilled workers in manufacturing and among professionals, technicians, and workers in crafts and related trades. Overskilled workers are overrepresented in the sales and transportation industries, as well as in the service and sales, and clerical support occupations. It is worth mentioning that there is no difference in workers' ages between the three skill mismatch groups (mean $=42$, standard deviation $=9.8$ ) or in the sizes of the firms that employ them.

It is important to note that underskilled workers participated more often in training and formal education. They also stated they learned more often on an informal basis than well-matched and overskilled workers did. The latter invested the least in their human capital. ${ }^{11}$ This may not be surprising, since these workers already had more skills than required in their job. This suggests that

\footnotetext{
${ }^{11}$ Multivariate analyses support these correlations. We find that initially underskilled workers are, on average, 6.8 percentage points more likely to participate in training courses, 4.8 percentage points more likely to engage in informal learning, and more intensively involved in informal learning than well-matched workers by approximately 0.55 of a standard deviation. Conversely, the initially overskilled have a lower probability of training participation ( -1.4 percentage points) and a lower probability of taking part in informal learning (-1.6 percentage points) in comparison with workers who started in a wellmatched job. In addition, informal learning intensity is also lower among the overskilled than among well-matched workers by approximately 0.94 of a standard deviation (see Table A4 in the Appendix).
} 
having a job that initially mismatches the skills of workers is related to participation in training as well as informal learning, which could influence workers' skill development.

\subsubsection{Control variables}

We explicitly include participation in formal education - which led to a higher degree while working for the current employer - as a control variable in our model. This variable measures human capital investments in the form of schooling rather than job-related learning. Formal education is a dummy variable for participation in formal educational programmes resulting in a higher or different educational degree while working for the current employer. We construct this variable by assigning the value one for those who achieved their highest level of education after they started to work with their current employer and zero otherwise. As shown in Table A2, 14 percent of all employees in our sample participated in formal education while working for their current employer. Formal education also seems to be positively correlated to skill development, a reason to include it as a control variable.

As suggested by human capital theory, we additionally control for age, gender, educational level (low, middle, and high), tenure, type of contract (permanent, fixed-term temporary, agency temporary, and no formal contract), occupation (nine one-digit ISCO categories), industry (10 onedigit ISIC categories), firm size (five categories), and country dummies. Moreover, we include dummies to control for major changes since the start of the job in regards to job position or job task content, ${ }^{12}$ working methods, ${ }^{13}$ and the need to learn new things ${ }^{14}$, which could affect the relationship of main interest in this paper. We also include a dummy variable that indicates whether the survey was conducted by telephone.

\section{ESTIMATION METHOD}

To estimate the relation between employees' job-related learning and skill development, we use ordered probit models. The fact that responses to our dependent variable are concentrated in some categories suggests that the meaning of certain categories is more expansive than others. In this case, OLS estimation is likely to give misleading results (Winship \& Mare, 1984; Long, 1997). Therefore, we consider the self-reported measure of individuals' skill changes as an ordinal structure in which the distances between the categories are unknown and allowed to be unequal.

\footnotetext{
${ }^{12}$ Major changes in the job position over tenure are considered, that is, if the worker has experienced a promotion, a demotion, a change of unit/department, or a substantial change in the nature of job tasks. These dummy variables are derived from the answers to the question, 'Since you started working for your current employer, have any of the following changes in your role taken place?' The respondent's options were: 'a) I have been promoted to a higher level position, b) I moved to a different unit/department, c) I have not been promoted or moved department but the nature of my tasks and responsibilities has changed, d) I now have a lower-level position than when I started, and e) no changes, my role has remained the same'.

${ }^{13}$ These dummy variables are derived from the answers to the question 'Since you started your main job have any of these changes taken place in your workplace?' The respondent's options taken into account were 'a) Changes to the technologies you use (e.g. machinery, ICT systems) and b) changes to your working methods and practices'.

${ }^{14}$ This categorical variable is derived from the question 'Has the need to learn new things increased, decreased or remained the same since you started your job with your current employer? Please use a scale of 0 to 10 , where 0 means it has decreased a lot, 5 means it has stayed the same and 10 means it has increased a lot'. Answers from zero to four are considered a decrease, whereas answers from six to 10 are considered an increase in the need of learning. Answer five is the base category.
} 
Let $S D_{i}$ denote an observable ordinal variable coded from zero to 10 based on responses to the individual skill change question described in the previous section. These choices are modelled based on an unobservable latent continuous variable $\left(S D_{i}^{*}\right)$ that can be expressed as a function of a set of observable factors $\left(Z_{i}\right)$ and unobservable factors $\left(u_{i}\right)$ using the following linear relationship:

$$
\begin{aligned}
S D_{i}^{*} & =Z_{i}^{\prime} \beta+u_{i} \\
& =\gamma^{\prime} X_{i}+\delta L_{i}+\zeta I S M_{i}+\psi\left(L_{i} * I S M_{i}\right)+u_{i}
\end{aligned}
$$

where $X$ is a vector of covariates composed of worker and firm characteristics along with a set of country dummies, $L$ is a vector of participation in training and informal learning variables, ISM is an indicator of the initial job-skill match, and $u_{i} \sim N(0,1)$. The existence of a set of $K-1$ ordered threshold parameters is also assumed, such that the individual responds with category $k$ if and only if $S D_{i}^{*} \epsilon\left[\theta_{k-1}, \theta_{k}\right]$. In general terms, we can write $\operatorname{Prob}\left(S D_{i}=k \mid Z_{i}\right)=\Phi\left(\theta_{k}-Z_{i}^{\prime} \beta\right)-\Phi\left(\theta_{k-1}-Z_{i}^{\prime} \beta\right)$ for $k=0, \ldots K$, where $\Phi(\cdot)$ denotes the cumulative distribution function of $u_{i}$ for the standard normal. The first and final intervals are open ended, so for $k=0, \Phi\left(\theta_{k-1}\right)=\Phi(-\infty)=0$ and for $k=10, \Phi\left(\theta_{k}\right)$ $=\Phi(+\infty)=1$. The regression parameters $\gamma, \delta, \zeta$, and $\psi$ and the $K-1$ threshold parameters are obtained by maximising the log-likelihood function subject to $\theta_{k}>\theta_{k-1}$ for all $k$. We use a robust clustered estimator of variance to allow for intragroup correlation at the country level (Wooldridge, 2010).

As described above, our analyses consider interactions between the learning variables $L$ (training, informal learning, and formal education) and the employee's initial skills match ISM. As Norton et al. (2004), Greene (2010), and Karaca-Mandic et al. (2011) have shown, the interpretation of interaction terms in linear models does not extend to nonlinear models. Basically, the interaction effect in nonlinear models cannot be evaluated by looking at the sign, magnitude, or statistical significance of the coefficient of the interaction term (Ai \&Norton, 2003). For nonlinear models that include interactions between categorical variables as in this paper, the interaction effect becomes the following discrete double difference:

$$
\begin{aligned}
\frac{\Delta^{2} \Phi\left(Z^{\prime} \beta\right)}{\Delta L * \Delta I S M} & =\frac{\Delta\left\{\Phi\left[\delta+\zeta I S M+\psi(L * I S M)+\gamma^{\prime} X\right]-\Phi\left[\zeta I S M+\gamma^{\prime} X\right]\right.}{\Delta I S M} \\
& =\Phi\left(\delta+\zeta+\psi+\gamma^{\prime} X\right)-\Phi\left(\delta+\gamma^{\prime} X\right)-\Phi\left(\zeta+\gamma^{\prime} X\right)+\Phi\left(\gamma^{\prime} X\right)^{2}
\end{aligned}
$$

Some implications need to be taken into account. First, the interaction effects in nonlinear models are conditional on the independent variables. Second, since two additive terms can be either positive or negative, the interaction effects could have opposite signs for different values of covariates and, therefore, the sign of $\psi$ does not necessarily reflect the sign of the interaction effects. Third, even if $\psi$ is zero, the interaction effects could be nonzero. Finally, the statistical significance tests of the interaction terms need to be associated with the entire double difference (Ai \& Norton, 2003; Norton et al., 2004). Taking these implications into account, we compute and report, as suggested by Long and Freese (2014) and Karaca-Mandic et al. (2011), full interaction marginal effects (crossdifferences) and their statistical significance to correctly interpret our results. 


\section{ESTIMATION RESULTS}

\subsection{Work-Related Learning and Skill Development}

We estimate an ordered probit regression for skill development that includes interactions between the work-related learning variables and the employee's initial skills match, as described in the previous section. The resulting coefficients, however, are not directly interpretable (Long, 1997; Greene, 2010; Long \& Freese, 2014). We therefore provide in Table 2 the corresponding average marginal effects (AMEs). ${ }^{15}$ To facilitate the interpretation of results, we compute AMEs in four categories: worsened skills (scores zero to four), no or hardly any change in skills (scores five and six), intermediate improvement of skills (scores seven and eight), and high improvement of skills (scores nine and 10). ${ }^{16}$

\section{[Insert Table 2 about here]}

In line with expectations from human capital theory, the results in Table 2 show that both participation in training and informal learning are significantly and positively associated with employees' skill development. These results also show that the AME of most of the explanatory variables related to the probability of high skill improvement is crucial in the way that it is offset by the distinctive probabilities of being in the other categories, zero to eight. These marginal effects confirm our descriptive results that the probability of high skill improvement is greater for employees who participated in training or informal learning in comparison with those who did not. More precisely, workers who participated in training are, on average, 8.3 percentage points more likely to have highly improved their skills than those who did not participate in any training course. Similarly, participation in training seems to reduce the odds of experiencing skill worsening and stagnation by 1.4 and 4.9 percentage points, respectively. In addition, employees' involvement in informal learning is also positively related to their skills improving. For instance, the likelihood of a high improvement of skills is $16.8,8.6$, and 3.4 percentage points greater for workers who, respectively, always, usually, and sometimes learn informally on the job, in comparison with those who are never involved in informal learning in their job.

Generally, our results so far suggest that the contribution of informal learning to workers' skill development seems to be larger than that of training participation. To provide more insight into this possibility, we perform an estimation that includes a dummy variable for informal learning ${ }^{17}$ instead of

\footnotetext{
${ }^{15}$ The coefficients are shown in Table A3 of the Appendix. This table shows the coefficients of our preferred specification in column (2) next to the resulting coefficients of a regression that does not include the interaction terms in column (1), for comparison purposes only. Our preferred specification (2) is shown to be better for at least two reasons: First, the likelihood ratio test $\left(\mathrm{LR} \mathrm{chi}^{2}=37.13\right)$ evaluated at 10 degrees of freedom is highly significant $\left(\mathrm{Prob}>\mathrm{chi}^{2}=0.0001\right)$, suggesting that the explanatory interaction terms included in the skill development is significant. Second, the difference of 57.1 points in the Bayesian information criterion between the two models provides strong support for the second model. More generally, we observe that the estimated threshold parameters of our models are not equally spread out, implying that the meaning of certain categories is, indeed, more expansive than others (specifically those corresponding to categories five to six, and nine to 10 ) and, therefore, that nonlinear estimations are more accurate.

${ }^{16}$ According to Long and Freese (2014), having more than two outcomes creates a challenge in summarising the effects of the independent variables in a way that fully reflects key substantive processes without overwhelming and distracting detail. We compute marginal effects in the four categories mentioned based on the criteria that the probabilities in the same group are of the same sign and similar size.

${ }^{17}$ This variable takes the value zero if the employee claimed to never be involved in informal learning on the job and takes the value one if the employee claimed to be involved in informal learning either sometimes, usually, or always.
} 
the original categorical variable. The predicted probabilities show that, indeed, the relationship of skill development with informal learning on the job is stronger and significantly different than that with training participation (see Panel A of Table A5 in the Appendix). This supports Mincer's (1974) claim that informal learning probably constitutes the major part of human capital investment in the workplace, given that workers likely spend much more time learning by doing in their job than in other training activities.

The results in Table 2 also suggest that the initial job-skill mismatch of workers significantly helps to explain their skill development while in the same job. We find that initially underskilled workers develop their skills more than those who started in a job that matched their skills well. Conversely, overskilled employees are more likely to experience skill worsening (by 1.5 percentage points) and stagnation (by 4.4 percentage points) than well-matched employees, confirming the evidence on skill depreciation shown by De Grip et al. (2008).

Regarding the covariates in our model, we find that the marginal probability of workers' skill development decreases with age and is lower for employees who are more educated, for those who have temporary or agency contracts instead of permanent contracts, and for individuals who have experienced a decrease in the need to learn new things since the start of their job. Conversely, it increases with participation in formal education and years of tenure (which compensates for the negative effect of age by approximately three times) and tends to be higher for female employees and for those who have experienced an increasing need for learning or a major change in their job position, job task content, or working process. Other controls indicate that high skill development is less likely for individuals employed in low-skilled occupations.

\subsubsection{Heterogeneity by Skill Mismatch Status at Job Entry}

As explained in Section 4, we include interaction terms in our main ordered probit model to see whether there is heterogeneity in the relation between job-related learning and workers' skill improvement due to differences in their initial job-skill mismatch status. Since the interpretation of these interactions is not as straightforward as it is for linear models, we compute the corresponding discrete double differences and statistical significance within and between the different skill mismatch statuses of workers. Two types of heterogeneity can be analysed. First, in Table 3, we show the difference in skill development of those who have been engaged in training or informal learning and those who have not within the same initial job-skill mismatch group.

\section{[Insert Table 3 about here]}

Table 3 shows that the general findings of Table 2, that those who participate in training or informal learning show a larger skill development, hold for all workers, independent of their initial skill mismatch status. Compared to workers with the same initial skill mismatch status, those who participated in training or informal learning are more likely to improve their skills than those who have not been involved in any learning activity. Nonetheless, there seems to be some heterogeneity in the 
magnitude of these relationships, particularly among workers with a job above their skill level. We find that these latter individuals do not show any significant difference in their skill improvement if they never participate in informal learning or if they do so only occasionally. Moreover, the association between their skill improvement and informal learning on a usual basis is shown to be weaker than - and significant with only 90 percent of confidence - within the well-matched and overskilled groups. This result suggests that informal learning needs to take place more often among underskilled employees to increase their probability of skill progress. Further analyses show that, within this group of underskilled employees, the relation of skill development with training is actually greater than that with informal learning, which is exactly the opposite within workers in a wellmatching job or a job below their skill level (see Panel B of Table A5 in the Appendix).

Remarkably, Table 3 also indicates that within the initially overskilled employees, training and informal learning are positively associated with their skill development. For instance, overskilled workers who participate in training or always engage in informal learning are, respectively, 8.9 and 20.6 percentage points more likely to develop their skills highly than overskilled workers who do not participate in training or who never engage in informal learning on the job. This could be because overskilled employees who invest in the development of their human capital acquire new skills that are different from those they have previously accumulated (e.g. non-technical or non-cognitive skills) or are more functional in offsetting skill depreciation. The latter explanation could be inferred from the significantly larger probabilities for overskilled workers in the skill change categories scored zero to four, and five and six (i.e. skill decline and more or less stable skills) in all types of learning.

Second, in Table 4, we show the actual interaction effects, that is, the differences in skill development between well-matched and underskilled employees who participated in work-related learning, on the one hand, and between well-matched and overskilled employees who participated in work-related learning, on the other hand. These are the actual interaction results, which need to be interpreted simultaneously with the AMEs for well-matched workers, the reference category, shown in the first panel of Table 3 .

\section{[Insert Table 4 about here]}

Altogether, these results clearly show differences between workers who started in a job that matched their skills well and those who started in a job at a level either above or below their own skill level. In comparison with well-matched employees, the strength of the relationship between workers' skill development and their participation in training or informal learning is stronger for those who were initially underskilled and weaker for those who were initially overskilled. For instance, underskilled employees who participated in training are 10.7 percentage points more likely to be in the two highest categories of skill development (nine to 10) than well-matched workers with similar learning investments. Similarly, underskilled workers who are always learning informally on the job are 11.2 percentage points more likely to improve their skills highly. This suggests that, for underskilled workers, who are probably employed in a more demanding job, participation in training or informal 
learning on the job is more favourable for their skill development. This could be due to richer learning opportunities at work and greater interest in maintaining their jobs (De Grip et al., 2008).

Conversely, overskilled employees who participated in training are, on average, 6.6 percentage points less likely to be in the two highest categories of skill development than similar workers in a well-matching job are. This implies, at the same time, that overskilled employees who participate in training are 1.1 percentage points more likely to experience skill depreciation (category zero to four) and 4 percentage points more likely to face stagnation in their skills (category five to six) than trained matched workers are. We find a similar pattern for informal learning. Compared to wellmatched workers with similar learning investments, overskilled employees who report that they always learn informally in their job are 5.8 percentage points less likely to improve their skills highly, which implies that, at the same time, they are 0.1 percentage points more likely to experience skill worsening and 3.7 percentage points more likely to face skill stagnation.

This does not mean that learning has a negative impact on the skill accumulation of overskilled workers but that the positive relation is much weaker than it is for workers in a wellmatching job. For example, whereas well-matched employees who participate in training and who are always learning informally have average probabilities of high skill development of 8.5 percent and 17.2 percent, respectively, the same probabilities for overskilled employees are, on average, 1.9 (8.5 minus 6.6) percent and 11.4 (17.2 minus 5.8) percent, respectively. This result suggests that training and informal learning on the job are much less beneficial for overskilled workers than for those who are employed in a well-matching job. Nonetheless, the more often overskilled workers engage in training or informal learning, the lower their probability of skill decline and stagnation. This result again suggests that the learning investments of overskilled workers are more functional in preventing skill depreciation than in fostering skill accumulation.

\subsubsection{Robustness of the Main Results}

Whereas the data we use are unique in their wide range of information about workers' skill development, learning participation, and initial mismatch status, there are also some drawbacks that could affect the precision of our estimates. In this section, we discuss the issues of endogeneity (omitted variables and measurement error) and the use and timing of self-reported measures as possible sources of bias. We argue that the probability of these potential sources of bias undermining the inferences and plausibility of the empirical findings of our study is very low.

\section{Endogeneity problems}

The most important concern is the endogeneity in our model due to omitted variable bias and possible measurement error. First, unobservable characteristics such as ability and motivation may affect employees' learning participation decisions as well as their own perceived levels of skill improvement. For instance, if highly motivated workers are more likely to participate in training and informal learning and also tend to see greater improvement in their skill levels, our results would be affected by a positive bias. However, the ability bias is expected to be negative, since more able individuals will 
tend to invest more in their human capital on the job but will also observe generally lower skill improvement, given the diminishing marginal utility of these investments. This would mean that our estimation results show a lower bound of the true effects.

Omitted variable bias might also arise because workers' own assessment of the (mis)match situation at job entry could vary with their personality traits, such as their degree of self-confidence. For example, individuals who are more confident about themselves will less often report an initial underskilled mismatch but might, simultaneously, be more likely to overestimate their own skill improvement. If these hypotheses are correct, then our results underestimate the true effects. Similarly, if individuals of higher ability are typically selected into well-matching or skill-challenging jobs, the expected endogeneity bias will also be negative. The opposite, however, would be expected with respect to omitted information on motivation.

Although the preceding analysis suggests more reasons to consider a negative bias for our results, it is not obvious how all these sources of endogeneity will balance out in an empirical approach. To provide some insight into these issues, we perform robustness analyses, taking into account the information on worker attitudes that is available in our dataset, that is, learning motivation and the importance of career development opportunities for respondents in the acceptance of their current job. ${ }^{18}$ Table 5 presents the main results.

Panel A of Table 5 shows that, as expected, learning motivation is significantly and positively related to workers' skill development. However, including this confounder does not substantially change our main estimation results, which remain significant and of similar magnitude as those in Table 2. ${ }^{19}$ Similarly, the estimation results in Panel B show that the importance workers gave to career development opportunities in accepting their current job is also positively associated with their skill development. Nevertheless, the predicted probabilities for training and informal learning remain positive and significant in this specification, indicating that our main findings remain the same when we account for workers' attitude towards career development opportunities. ${ }^{20}$ These results all hold for overskilled, underskilled, and well-matched employees. ${ }^{21}$

\section{[Insert Table 5 about here]}

\footnotetext{
${ }^{18}$ The variable for learning motivation is a standardised index derived from the question ' $O$ a scale from 0 to 10 , where 0 is strongly disagree and 10 strongly agree, please indicate to what extent do you agree or disagree with the following statements: a) I enjoy learning for its own sake, b) I try to relate learning to practical issues, and c) I prefer to have others plan my learning'. The variable for career development opportunities is derived from the question 'Before you started working for your current employer, how important, if at all, were the opportunities for job career development in your decision to accept the job? Please use a scale of 0 to 10 where 0 means not at all important, 5 means moderately important and 10 means essential'.

${ }^{19}$ Although this holds for all workers with low or high learning motivation, we observe that workers with stronger learning motivation show a greater skills increase in relation to both training and informal learning.

${ }^{20}$ Although this holds for all workers who responded with low or high importance to their job career development opportunities, we observe that workers who considered career opportunities more important in accepting the job show a greater skills increase in relation to both training and informal learning.

${ }^{21}$ Detailed tables of results within and across skill mismatch statuses are available upon request.
} 
Measurement error and the timing of self-assessed variables

A second concern is the possible bias of our results due to systematic measurement errors in the selfassessed measures we use for our analyses. Our main dependent variable, skill development, and our key moderator variable in the model, initial skill mismatch status, are subjective self-assessments of workers based on a retrospective appraisal of the period since the respondent started the current job. The use of subjective data for research in topics such as this is legitimate, particularly given the difficulty of obtaining objective indicators for these variables. However, there are two major possible problems with these data. First, the self-assessed information could involve recall error. We consider that the magnitude of this type of measurement error is likely to differ across respondents due to the variation of time elapsed since job entry. Second, it could be possible that a worker's skill development took place before the worker participated in on-the-job learning. We attempt to capture these two potential problems by estimating our main model for workers with different tenure. The idea behind these robustness analyses is that the degree to which recall bias or the reverse order of skill development and on-the-job learning most likely depends on the time elapsed since the start of the job.

We therefore first estimate for each additional year of tenure the corresponding probability of high skill improvement (i.e. categories nine to 10 of our dependent variable) in relation to both training and informal learning. Figure 4 shows the estimation results evaluated over years of tenure. The left-hand side represents the AMEs of training and the right-hand side the AMEs of (sometimes and always) informal learning. We observe that, for both forms of learning, the predicted marginal probabilities of high skill improvement are, as expected, slightly increasing during the first period (six years) of tenure and then continue in a constant pattern until the later years of tenure. Nonetheless, the confidence intervals show that the point estimates for the various years of tenure are not significantly different from each other. This suggests that potential sources of bias due to systematic measurement error have not influenced our main results. This result also holds for the heterogeneity of our main findings between overskilled, underskilled, and well-matched employees, as shown in Figure A1 and Figure A2 in the Appendix.

\section{[Insert Figure 4 about here]}

Second, we assess the accuracy of our main results by comparing them with estimation results on more selective samples of workers for whom the recall bias and/or the reverse order of skill development and on-the-job learning could be considered to be at a minimum. These are workers with shorter periods of job tenure or those who have finished formal education more recently and are relatively younger. We present the corresponding results in Table 6. This table shows that the estimation results are similar in magnitude and significance to our main results in Table 2. This suggests that, although a bias due to measurement error in self-assessed variables could be important for the precision of measuring the true effects, this bias is not likely to be large enough to challenge the plausibility of our findings.

[Insert Table 6 about here] 


\subsubsection{Additional Evidence on Job-Related Human Capital Investments and Skill Development}

In this section, we analyse whether there are any differences in the relevance of different types of training and informal learning for workers' skill development. First, we distinguish between training participation during and outside working hours, and between training paid by the employer and by the employee. Second, we distinguish between informal learning from others (co-workers and supervisors), informal learning by trial and error, and informal leaning by self-study.

\section{Different types of training}

The results in Panel A of Table 7 show some heterogeneity with regards to different types of training for workers with a different mismatch status. We observe that employees in a well-matching job who followed training courses during working hours show greater improvement in their skills than those who participated in training outside working hours. For underskilled employees, the contribution of training outside working hours does not seem to be significant, whereas among overskilled workers the difference between training during and outside working hours is much lower (and statistically insignificant) in comparison with the other two groups of workers. Concerning the main funding sources of training, we find that, for well-matched and underskilled employees, the contribution of training paid by the employer to their skill development seems to be larger than that of training paid by the employees themselves. Conversely, we again observe that, among overskilled workers, the difference between training paid by the employer and training paid by the employee is lower and statistically insignificant.

This heterogeneity could arise from differences in the relevance of the training content for workers with a different (mis)match. ${ }^{22}$ Since overskilled workers participate more often than others in training outside working hours and financed by themselves, it is plausible that they consider the investment in this training to be more general and useful to improve or update skills they do not use in their job. This could provide them with more opportunities to find a better job match in their current or other firms. This could explain why, in Panel B of Table 7, training outside working hours and training paid by the employee seem to be as useful for the skill development of overskilled workers as it is for the well-matched, whereas training during working hours and training paid by the employer appear to be less beneficial for the former group. Lastly, Panel B of Table 7 also suggests that, in comparison with employees in a well-matching job, training participation seems to be more beneficial for underskilled workers, regardless of the funding source and whether it occurs during or outside working time.

\section{[Insert Table 7 about here]}

\section{Different types of informal learning}

To analyse whether there are any differences in the relevance of different types of informal learning for workers' skill development, we distinguish between informal learning from others (co-workers and

\footnotetext{
${ }^{22}$ An alternative explanation could be that the duration of these different types of training differs across workers. We, cannot, however, analyse this possibility, since there is no information on training duration/intensity available in our dataset.
} 
supervisors), informal learning by trial and error, or learning by doing, and informal leaning by selfstudy. Since the question for the different types of informal learning was only asked to those who reported a positive skill change (i.e. categories scoring six to 10), here we can use a sample of only 31,385 observations. The results in Table 8 show that, indeed, the relation between informal learning and skill improvement differs with the type of informal learning and it is heterogeneous across employees with different initial skill mismatch situations. We find, as shown in Panel A of Table 8, that, for workers in well-matching jobs, informal learning from colleagues and supervisors seems to contribute to their skill improvement as much as informal learning by trial and error and self-study. Underskilled workers, however, show greater skill improvement when learning by self-study than when learning from others, while there does not seem to be any significant difference in skill improvement between those who are involved in learning by trial and error and those who are not. In contrast, for the skill improvement of overskilled workers, informal learning from colleagues and supervisors seems to be as important as learning by doing, whereas learning by self-study does not make any significant contribution. ${ }^{23}$ Panel B of Table 8 again shows that, in comparison with wellmatched workers with similar informal learning participation, the relation between skill development and all three types of informal learning is stronger among workers with a job above their skill levels, and weaker for those with a job below their skill level.

\section{[Insert Table 8 about here]}

\subsection{On-the-job Learning Complementarity and Workers' Skill Development}

In this section we raise the question whether or not the complementarity (or substitutability) between training and informal learning at work is related to the development of workers' skills.

First, we examine whether there is complementarity or substitution between training and informal learning. The estimation results of a multivariate analysis show that, as expected, training and informal learning on the job complement each other (see Table 9). ${ }^{24}$ This complementarity holds for all well-matched, underskilled, and overskilled workers, although the strength of this complementarity differs between the three skill-mismatch groups (see Tables A6 and A7 in the Appendix). In comparison with initially well-matched workers, the complementarity is stronger among those who were initially underskilled for their job and slightly weaker but still positive among initially overskilled employees.

\section{[Insert Table 9 about here]}

Second, to find out whether this complementarity plays a role in workers' skill development, we introduce interaction terms between the work-related learning variables in our main model and estimate the corresponding AMEs of training and informal learning conditionally evaluated on each

\footnotetext{
${ }^{23}$ Note, however, that we cannot make any inference regarding skill maintenance or decline due to sample truncation.

${ }^{24}$ The complementarity means that, on the one hand, the frequency of informal learning increases when a worker participates in training and, on the other hand, the average individual probability of training participation is higher the more often the worker engages in informal learning.
} 
other. This allows us to assess if the investment in each type of learning is related to any additional increase in the probability of skill improvement when the worker also engages in the other type of learning and if the probability of skill improvement increases further when the worker engages in both forms of learning. Panel A of Table 10 shows that this is indeed the case. For example, on average, the probability of a high improvement of skills associated with training participation increases from 6.9 to 9.5 percentage points if the worker always participates in informal learning instead of never doing so. ${ }^{25}$ The same holds for the skill development likelihood related to informal learning; it is significantly higher if workers also participate in training. This result suggests that training and informal learning provide workers with complementary skills rather than substitutable skills. Moreover, this complementarity appears to favour their skill accumulation. The interaction outcome shown in Panel B of Table 10 indicates that the probability of a high improvement of skills when employees engage in both types of work-related learning (0.250) is significantly higher than the sum (0.224) of the partial contributions of training (0.069) and informal learning (0.155) if workers participate in only one of these forms of learning. ${ }^{26}$ Consistent with Cunha and Hekman's (2007) notions of direct complementarity and cross-productivity, the complementarity between training and informal learning is positively related to a significant additional improvement of workers' skills. This suggests that not only training participation encourages informal learning and vice versa, but also the skills acquired through both forms of work-related learning seem to boost each other in a multiplier process that further reinforces the skill development of workers who participate in both types of workrelated learning.

\section{[Insert Table 10 about here]}

\subsubsection{Heterogeneity in Learning Complementarity and Workers' Skill Development}

To assess if the additional improvement of skills associated with the complementarity between training and informal learning holds to the same extent for initially well-matched, underskilled, and overskilled employees, we estimate the AMEs of a three-way interaction term between the two forms of learning and the indicator for the initial skill mismatch in our main model. In Table 11 we present the most relevant estimation results. ${ }^{27}$ The table shows that the complementarity between training and informal learning relates to additional gains in skill development only for initially well-matched ${ }^{28}$ and overskilled $^{29}$ workers. Although training and informal learning are both associated with greater

\footnotetext{
${ }^{25}$ This difference $(0.026)$ is significant with 99 percent confidence $\left(\mathrm{Chi}^{2}(1)=51.3, \mathrm{p}=0.000\right)$. This is equivalent to the statistical difference (0.026) between the probability of a high improvement of skills associated with informal learning 'always' if workers also participate in training $(0.181)$ and if they do not participate in training $(0.155)$. This latter difference is also significant with 99 percent confidence $\left(\mathrm{Chi}^{2}(1)=35.9, \mathrm{p}=0.000\right)$.

${ }^{26}$ This difference $(0.026)$ is significant with 99 percent confidence $\left(\mathrm{Chi}^{2}(1)=127.1, \mathrm{p}=0.000\right)$ and equal to the corresponding difference between the conditional contributions of training and informal learning, as explained in footnote 25 . ${ }^{27}$ Complete tables are available upon request.

${ }^{28}$ For workers in an initially well-matching job, the probability of a high improvement of skills when they engage in both types of work-related learning $(0.253)$ is higher than the sum $(0.232)$ of the partial contributions of training $(0.073)$ and informal learning (0.159). The difference $(0.021)$ is significant with 99 percent confidence $\left(\mathrm{Chi}^{2}(1)=96.7 \mathrm{p}=0.000\right)$.

${ }^{29}$ For initially overskilled workers, the probability of a high improvement of skills when they engage in both types of workrelated learning $(0.289)$ is higher than the sum $(0.255)$ of the partial contributions of training $(0.070)$ and informal learning $(0.187)$. The difference $(0.032)$ is significant with 99 percent confidence $\left(\mathrm{Chi}^{2}(1)=159.6, \mathrm{p}=0.000\right)$.
} 
improvement in the skills of underskilled workers, the complementarity between these two types of learning does not seem to add any further to that skill improvement. ${ }^{30}$ If we extend the analysis of Cunha and Heckman (2007) to the workplace, as presented in Section 2.2, our findings are consistent with their notion of the skills multiplier. In their model, more complementarity of human capital implies greater productivity of new investments but, as the degree of complementarity increases, the role of the skill multiplier decreases. According to our findings, this holds for all three job-skill (mis)match groups in our analysis. Together, the results of Sections 5.1 and 5.2 suggest that having a higher initial stock of skills than required for the job implies a greater skill multiplier potential. However, this potential seems to be hampered by the tendency of overskilled workers to participate much less in both training and informal learning, in comparison to workers in a well-matching job. This situation not only seems to diminish the complementarity of human capital among overskilled workers, but also relates to a lower probability of developing their skills. Conversely, in comparison to well-matched workers, those who were initially underskilled show a higher complementarity of human capital as they participate more often in training and informal learning, which seems to compensate for their disadvantage in the skill multiplier potential. This suggests that work-related learning helps in reducing the initial skill gap of underskilled workers. However, as implied by Carneiro and Heckman (2003), this learning could be more costly due to (1) the greater need for complementary investments in both training and informal learning to compensate for their initial disadvantage and (2) our finding that their lower initial stock of job skills seems to weaken the multiplier potential of these investments for their skill development. Nevertheless, initially underskilled workers still show the greatest improvement in skills among all workers who invest in their human capital while on the job.

\section{[Insert Table 11 about here]}

\section{CONCLUSIONS}

In this paper, we have analysed the extent to which training and informal learning on the job are related to the skill development of workers in 28 European countries. Consistent with assumptions from human capital theory, we find that employees who have been involved in training and informal learning show greater improvement of their skills. In line with Mincer's (1974) claim, we find that informal learning is more strongly related to the improvement of workers' skills than training participation is. However, this does not mean that participation in training is not important. Training and informal learning are shown to be complementary and this complementarity seems to further favour workers' skill development, since we find that those who participate in both forms of learning show a significant additional improvement of their skills. This is likely explained by the complementarity and cross-productivity between investments in human capital and their impact in the multiplier process of skills (Cunha \& Heckman, 2007) that can also occur in the workplace, making the skills acquired by training and informal learning mutually-reinforcing.

\footnotetext{
${ }^{30}$ For initially underskilled workers, the probability of a high improvement of skills when they engage in both types of workrelated learning $(0.213)$ is statistically equivalent to the sum $(0.212)$ of the partial contributions of training $(0.079)$ and informal learning $(0.133)\left(\mathrm{Chi}^{2}(1)=0.4, \mathrm{p}=0.527\right)$.
} 
We also analysed the heterogeneity in the relation between the two forms of job-related learning and workers' skill development with respect to their initial skill mismatch status. First, our results show that workers who participate in training or informal learning are more likely to improve their skills considerably than those with the same initial skill mismatch status who have not been involved in any learning activity. This result suggests that on-the-job learning helps improve the skills of both matched and mismatched workers. Second, compared to those who started in a job that matched well their skills, the skill development of underskilled workers appears to benefit the most from both training and informal learning, whereas the skill development of the overskilled benefits the least. In particular, human capital investments in the latter group seem to be more functional in offsetting skill depreciation and preserving their skill levels than in fostering skill accumulation.

The finding that underskilled employees who participate in training and informal learning show the largest increase in their skills suggests that human capital investments on the job could help to improve the job-skill match of these workers by closing the gap between their initial skill levels and the skills required in the workplace (Arulampalam et al., 2004). This could be motivated by a greater interest of these employees in maintaining their job or by richer learning opportunities offered at work (De Grip et al., 2008). In contrast, the finding that overskilled workers have the lowest probabilities of skill improvement and participation in both training and informal learning suggests that work-related human capital investments for these workers could be more relevant in maintaining the skills they do not use in their job or as a mitigating factor counteracting skill obsolescence (Mincer \& Ofek, 1982; De Grip \& van Loo, 2002), which could provide them with prospects to find a better job match in the current firm or other firms. It is, therefore, important to recognise the overskilled workers' need to participate in training and informal learning, even though they have the least increase in skills.

In our study, we find further heterogeneity across workers with a different job-skill (mis)matches regarding the (1) complementary of human capital investments and (2) the multiplier potential of these investments for their skill development. On the one hand, overskilled workers are shown to have a greater skill multiplier potential but, at the same time, significantly lower rates of participation in both training and informal learning and lesser complementarity between these human capital investments than employees in a well-matching job. Accordingly, initially overskilled workers show the lowest probabilities of skill improvement. On the other hand, underskilled workers are more likely to participate in both training and informal learning and show greater complementarities between these human capital investments, which seems to compensate for the disadvantage in the skills multiplier potential, given their lower stock of job-skill in comparison with well-matched employees. Underskilled workers therefore show the greatest probabilities of skill improvement among all workers who participate in work-related learning.

Our study then suggests that the interaction between work-related human capital investments and the utilisation of workers' initial stock of skills in their job plays an important role in the process of skill development. According to the literature on skills formation (e.g. Cunha \& Heckman, 2007) as 
well as the literature on skill obsolescence (e.g. Mincer \& Ofek, 1982, De Grip \& van Loo, 2002), being overskilled at job entry could be a negative context, not only because a worker's initial stock of skills may deteriorate due to non-use, but also because this deterioration may decrease the productivity and complementarity of further learning investments in the process of human capital accumulation. In contrast, being underskilled could be a positive context to raise the level and productivity of further learning investments. However, as implied by Carneiro and Heckman (2003), the elimination of the skill gap of these workers might be more costly due to the greater need for complementary investments in both training and informal learning and because their lower initial stock of job skills seems to weaken the multiplier potential of these investments in comparison with workers whose skills better match their job requirements.

Since lifelong learning and workers' skill development are essential for the productivity of firms with rapidly changing skill demands and for economic progress (World Economic Forum, 2014), knowledge about heterogeneities in the role of training and informal learning in workers' skill development with respect to their initial skill mismatch is crucial to make efficient decisions on human capital investments. Optimal decisions on investment in lifelong learning could contribute to reduce the misalignment between workers' potential productivity and the optimal productivity of their jobs. In this respect, it is important that more - in particular longitudinal - research be done on the causal effects of both formal training and informal learning on workers' skill development taking into account the basis and extent of the skill (mis)match they face in their jobs.

\section{REFERENCES}

Ai, C., \& Norton, E. (2003). Interaction terms in logit and probit models. Economics Letters, 80(1), 123-129.

Acemoglu, D., \& Pischke, J. (1999). The structure of wages and investment in general training. Journal of Political Economy, 107(3), 539-572.

Allen, J., \& van der Velden, R. (2001). Educational mismatches versus skill mismatches: Effects on wages, job satisfaction, and on-the-job search. Oxford Economic Papers, 53(3), 434-452.

Arulampalam, W., Booth, A., \& Bryan, M. (2004). Training in Europe. Journal of the European Economic Association, 2(2-3), 346-360.

Bartel, A. (1994). Productivity gains from the implementation of employee training programs. Industrial Relations: A Journal of Economy and Society, 33(4), 411-425.

Bartel, A. (2000). Measuring the employer return on investment in training: Evidence from the literature. Industrial Relations, 39(3), 502-524.

Barrett, A., \& O'Connell, P. (2001). Does training generally work? The returns to in-company training. Industrial and Labour Relations Review, 54(3), 647-662.

Becker, G. (1964). Human capital: A theoretical and empirical analysis with special reference to education. New York: Columbia University Press.

Ben-Porath, Y. (1967). The production of human capital and the life cycle of earnings. The Journal of Political Economy, 75(4), 352-365.

Blazquez, M., \& Jansen, M. (2008). Search, mismatch and unemployment. European Economic Review, 52(3), $498-526$.

Blundell, R., Dearden, L., Meghir, C., \& Sianesi, B. (1999). Human capital investment: The returns from education and training to the individual, the firm and the economy. Fiscal Studies, 20(1), 1-23.

Carneiro, P., \& Heckman, J. (2003) Human capital policy. NBER Working Paper No. 9495. Cambridge, MA.

Chevalier, A. (2003). Measuring Overeducation. Economica, 70 (279), 509-531. 
Chevalier, A., \& Lindley, J. (2009). Overeducation and the skills of UK graduates. Journal of the Royal Statistics Society, 172(2), 307-337.

Cunha, F., \& Heckman, J. (2007). The technology of skills formation. American Economic Review, 97(2), 3147.

De Corte, E. (2003). Transfer as the productive use of acquired knowledge, skills and motivations. Current Directions in Psychological Science, 12(4), 142-146.

De Grip, A., \& Sauermann, J. (2012). The effects of training on own and co-worker productivity: Evidence from a field experiment. The Economic Journal, 122(560), 376-399.

De Grip, A., \& Sauermann, J. (2013). The effect of training on productivity: The transfer of on-the-job training from the perspective of economics. Educational Research Review, 8, 28-36.

De Grip, A., Bosma, H., Willems, D., \& van Boxtel, M. (2008). Job-worker mismatch and cognitive decline. Oxford Economic Papers, 60(2), 237-253.

De Grip, A., \& van Loo, J. (2002). The economics of skills obsolescence: A review. In A. de Grip, J. van Loo \& K. Mayhew (Eds.), The economics of skills obsolescence: Theoretical innovations and empirical applications (pp. 1-26). Research in Labor Economics 21, Amsterdam: Elsevier Science.

Dearden, L., Reed, H., \& van Reenen, J. (2006). The impact of training on productivity and wages: Evidence from British panel data. Oxford Bulletin of Economics and Statistics, 68(4), 397-421.

Destré, G., Lévy-Garboua, L., \& Sollogoub, M. (2008). Learning from experience or learning from others? Inferring informal training from a human capital earnings function with matched employer-employee data. The Journal of Socio-Economics, 37(3), 919-938.

Di Pietro, G., \& Urwin, P. (2006). Education and skill mismatch in the Italian graduate labour market. Applied Economics, 38(1), 79-93.

Dolton, P., \& Silles, M. (2008). The effects of overeducation on earnings in the graduate labour market. Economics of Education Review, 27(2), 125-139.

European Commission (2010). Europe 2020: A strategy for smart, sustainable and inclusive growth. Brussels: European Commission.

Green, F., Ashton, D., \& Felstead, A. (2001). Estimating the determinants of supply of computing problemsolving, communication, social, and teamworking skills. Oxford Economic Papers, 53(3), 406-433.

Green, F., \& Zhu, Y. (2010). Overqualification, job dissatisfaction, and increasing dispersion in the returns to graduate education. Oxford Economic Papers, 62(4), 740-763.

Green, F., \& McIntosh, S. (2007), Is there a genuine under-utilization of skills amongst the over-qualified? Applied Economics, 39(4), 427-439.

Greene, W. (2010) Testing hypotheses about interaction terms in non-linear models. Economic Letters, 107(2), 291-296.

Görlitz, K. (2011). Continuous training and wages: An empirical analysis using a comparison-group approach. Economics of Education Review, 30(4), 691-701

Groot, W. (1996). The incidence of, and returns to overeducation in the UK. Applied Economics, 28(10), 13451350.

Hartog, J. (2000). Overeducation and earnings: Where are we, where should we go? Economics of Education Review, 19(2), 131-147.

Heckman, J. (1976). A life-cycle model of earnings, learning, and consumption. Journal of Political Economy, 84(4), 11-44.

Heckman, J. (2007) The economics, technology and neuroscience of human capability formation. IZA discussion Paper No. 2875. Institute for the Study of Labour.

Hersch, J. (1991). Education match and job match. Review of Economics and Statistics. 73(1), 140-144.

Ipsos MORI (2014). Cedefop European skills survey: Data collection and quality report. London, Ipsos MORI publications.

Karaca-Mandic, P., Norton, E., \& Dowd, B. (2012). Interaction terms in nonlinear models. Health Services Research, 47(1), 255-274.

Killingsworth, M. (1982). "Learning-by-doing" and "investment in training": A synthesis of two "rival" models of the life cycle. The Review of Economic Studies, 49(2), 263-271.

Leuven, E., \& Oosterbeek, H. (2008). An alternative approach to estimate the wage returns to private-sector training. Journal of Applied Econometrics, 23(4), 423-434. 
Levitt, S., List, J., \& Syverson, C. (2012). Toward an understanding of learning by doing: evidence from an automobile assembly plant. NBER Working Paper No. 18017. Cambridge: MA.

Linsley, I. (2005). Causes of overeducation in the Australian labour market. Australian Journal of Labour Economics, 8(2), 121-144.

Long, J. (1997). Regression models for categorical and limited dependent variables. London: Sage Publications.

Long, J., \& Freese, J. (2014). Regression models for categorical dependent variables in Stata. College Station, TX: Stata Press.

Lowenstein, M., \& Spletzer, J. (1998). Dividing the costs and returns to general training. Journal of Labor Economics, 16(1), 142-171.

Mavromaras, K., \& McGuinness, S. (2012). Overskilling dynamics and education pathways. Economics of Education Review, 31(5), 619-628.

Mavromaras, K., McGuinness, S., O’Leary, N., Sloane, P., \& Fok, Y. (2010). The problem of overskilling in Australia and Britain. Manchester School, 78(3), 219-241.

McGuinness, S. (2006). Overeducation in the labour market. Journal of Economic Surveys, 20(3), 387-418.

McGuinness, S., \& Byrne, D. (2014). Examining the relationships between labour market mismatches, earnings and job satisfaction among immigrant graduates in Europe. IZA Discussion Paper No. 8440. The Institute for the Study of Labor.

McGuinness, S., \& Sloane, P. (2011). Labour market mismatch among UK graduates: An analysis using REFLEX data. Economics of Education Review, 30(1), 130-145.

McGuinness, S., \& Wooden, M. (2009). Overskilling, job insecurity and career mobility. Industrial Relations, 48(2), 265-286.

Messinis, G., \& Olekalns, N. (2007), Skill mismatch and training in Australia: Some implications for policy. Australian Economic Review, 40(3), 300-306.

Messinis, G., \& Olekalns, N. (2008). Returns to training and skill mismatch: Evidence from Australia. CSES Working Paper No. 40. Victoria University.

Mincer, J. (1962). On-the-job training: Costs, returns, and some implications. Journal of Political Economy, $70(5), 50-79$.

Mincer, J. (1974). Schooling, experience and earnings. New York: Columbia University Press.

Mincer, J., \& Ofek, H. (1982). Interrupted work careers: depreciation and restoration of human capital. Journal of Human Resources, 17(1), 3-24.

Norton, E., Wang, H., \& Ai, C. (2004). computing interaction effects and standard errors in logit and probit models. Stata Journal, 4(2), 154-167.

O'Connell, P., \& Byrne, D. (2012). The determinants and effects of training at work: bringing the workplace back in. European Sociological Review, 28(3), 283-300.

O’Leary, N., Sloane, P., McGuinness, S., O’Connor, P., \& Mavromaras, K. (2009). A taxonomy of skill mismatch. Report to Cedefop. European Centre for the Development of Vocational Training (Cedefop).

Rosen, S. (1975). Measuring the obsolescence of knowledge. In F. Juster (Ed.) Education, income and human behaviour (pp. 199-232). New York: McGraw-Hill.

Sepulveda, F. (2010). Training and productivity: evidence for US manufacturing industries. Oxford Economic Papers, 62(3), 504-528

Sloane, P., Battu, H., \& Seaman, P. (1996). Overeducation and the formal education/experience and training trade-off. Applied Economics Letters, 3(8), 511-515.

Sloane, P., Battu, H., \& Seaman, P. (1999). Overeducation, undereducation and the British labour market. Applied Economics, 31(11), 1437-1453.

van Smoorenburg, M., \& van der Velden, R. (2000). The training of school-leavers: Complementarity or substitution? Economics of Education Review, 19(2), 207-217.

Verhaest, D., \& Omey, E. (2009). Objective overeducation and worker well-being: a shadow price approach. Journal of Economic Psychology, 30(3), 469-481.

Winship, C., \& Mare, R. (1984). Regression models with ordinal variables. American Sociological Review, 49(4), 512-525.

Wooldridge, J. (2010). Econometric analysis of cross section and panel data. Cambridge, MA: MIT Press.

World Economic Forum (2014). Matching skills and labour market needs: Building social partnerships for better skills and better job. Geneva: Global agenda council on employment, World Economic Forum. 
TABLES AND FIGURES

Table 1. Distribution of skill development since job entry

\begin{tabular}{crr} 
Skill change & $\%$ \\
\hline My skills have worsened a lot & 0 & 0.2 \\
1 & 0.2 \\
2 & 0.5 \\
3 & 0.8 \\
My skills have stayed the same & 5 & 1.3 \\
& 6 & 7.5 \\
& 7 & 16.9 \\
& 8 & 25.0 \\
& 9 & 17.1 \\
My skills have improved a lot & 10 & 19.7 \\
\hline
\end{tabular}

Table 2. Average marginal effects (AMEs) on workers' skill development

\begin{tabular}{|c|c|c|c|c|}
\hline Skill change & $0-4$ & $5-6$ & $7-8$ & $9-10$ \\
\hline \multirow[t]{2}{*}{ Training } & $-0.014^{* * * *}$ & $-0.049^{* * * *}$ & $-0.020^{* * * *}$ & $0.083^{* * * *}$ \\
\hline & $(0.001)$ & $(0.004)$ & $(0.003)$ & $(0.007)$ \\
\hline \multirow[t]{2}{*}{ IL sometimes } & $-0.012^{* * *}$ & $-0.025^{* * *}$ & 0.003 & $0.034^{* *}$ \\
\hline & $(0.004)$ & $(0.011)$ & $(0.004)$ & $(0.016)$ \\
\hline \multirow[t]{2}{*}{ IL usually } & $-0.021^{* * *}$ & $-0.056^{* * * *}$ & $-0.009^{* * *}$ & $0.086^{* * * *}$ \\
\hline & $(0.005)$ & $(0.012)$ & $(0.004)$ & $(0.012)$ \\
\hline \multirow[t]{2}{*}{ IL always } & $-0.029^{* * * *}$ & $-0.099^{* * * *}$ & $-0.040^{* * * *}$ & $0.168^{* *_{*}^{* * *}}$ \\
\hline & $(0.005)$ & $(0.012)$ & $(0.006)$ & $(0.016)$ \\
\hline \multirow[t]{2}{*}{ Formal education } & $-0.008^{* * *}$ & $-0.030^{* * * *}$ & $-0.015^{* * * *}$ & $0.053^{* * * *}$ \\
\hline & $(0.001)$ & $(0.004)$ & $(0.003)$ & $(0.007)$ \\
\hline \multirow[t]{2}{*}{ Initially underskilled } & $-0.012^{* * * *}$ & $-0.056^{* * * *}$ & $-0.041^{* * * *}$ & $0.109^{* * * *}$ \\
\hline & $(0.001)$ & $(0.003)$ & $(0.003)$ & $(0.006)$ \\
\hline \multirow[t]{2}{*}{ Initially overskilled } & $0.015^{* * * *}$ & $0.044^{* * * *}$ & $0.007^{* * * *}$ & $-0.066^{* * * *}$ \\
\hline & $(0.002)$ & $(0.006)$ & $(0.002)$ & $(0.008)$ \\
\hline \multirow[t]{2}{*}{ Age } & $0.000^{* * *}$ & $0.001^{* * * *}$ & $0.001^{* * *}$ & $-0.002^{* * *}$ \\
\hline & $(0.000)$ & $(0.000)$ & $(0.000)$ & $(0.000)$ \\
\hline \multirow[t]{2}{*}{ Female } & $-0.010^{* * * *}$ & $-0.039^{* * * *}$ & $-0.021^{* * * *}$ & $0.070^{* * * *}$ \\
\hline & $(0.001)$ & (0.004) & $(0.002)$ & $(0.006)$ \\
\hline \multirow[t]{2}{*}{ Intermediate level education } & $0.003^{* * *}$ & $0.013^{* * *}$ & $0.009^{* * *}$ & $-0.025^{* * *}$ \\
\hline & $(0.001)$ & $(0.004)$ & $(0.003)$ & $(0.009)$ \\
\hline \multirow[t]{2}{*}{ High level education } & $0.010^{* * * *}$ & $0.038^{* * * *}$ & $0.023^{* * *}$ & $-0.071^{* * * *}$ \\
\hline & $(0.002)$ & $(0.005)$ & $(0.003)$ & $(0.010)$ \\
\hline \multirow[t]{2}{*}{ Years of tenure } & $-0.001^{* * *}$ & $-0.003^{* * *}$ & $-0.002^{* * *}$ & $0.006^{* * * *}$ \\
\hline & $(0.000)$ & $(0.000)$ & $(0.000)$ & $(0.000)$ \\
\hline
\end{tabular}

This table shows AMEs computed on the ordered probit specification (2) in Table A3 in the Appendix. The dependent variable skill change is measured by 11 ordinal categories from zero to $10(0=$ skills have worsened a lot, $5=$ skills have stayed the same, $10=$ skills have improved a lot). AMEs on skill change are grouped into four categories: worsened (0-4), no or hardly any change (5-6), intermediate improvement (7-8), and high improvement (9-10). The AME for categorical variables is the discrete change from the base level. Standard errors clustered at country level are shown in parentheses. ${ }^{*} p<0.10,{ }^{* *} p<0.05,{ }^{* * *} p$ $<0.01 . \mathrm{N}=37,285$. 
Table 3. AMEs of work-related learning on workers' skill development within job-skill (mis)match groups

\begin{tabular}{|c|c|c|c|c|}
\hline Skill change & $0-4$ & $5-6$ & $7-8$ & $9-10$ \\
\hline \multicolumn{5}{|c|}{ Initially well matched } \\
\hline Training & $\begin{array}{c}-0.012^{* * * *} \\
(0.001)\end{array}$ & $\begin{array}{c}-0.051^{* * *} \\
(0.004)\end{array}$ & $\begin{array}{c}-0.022^{* * * *} \\
(0.002)\end{array}$ & $\begin{array}{c}0.085^{* * * *} \\
(0.007)\end{array}$ \\
\hline IL sometimes & $\begin{array}{c}-0.008^{* *} \\
(0.003)\end{array}$ & $\begin{array}{c}-0.026^{* *} \\
(0.011)\end{array}$ & $\begin{array}{c}-0.005^{* * *} \\
(0.002)\end{array}$ & $\begin{array}{l}0.039^{* * *} \\
(0.020)\end{array}$ \\
\hline IL usually & $\begin{array}{c}-0.015^{* * * *} \\
(0.005)\end{array}$ & $\begin{array}{c}-0.055^{* * *} \\
(0.015)\end{array}$ & $\begin{array}{c}-0.017^{* * * *} \\
(0.003)\end{array}$ & $\begin{array}{c}0.087^{* * * *} \\
(0.015)\end{array}$ \\
\hline IL always & $\begin{array}{c}-0.023^{* * * *} \\
(0.005)\end{array}$ & $\begin{array}{c}-0.099^{* * * *} \\
(0.015)\end{array}$ & $\begin{array}{c}-0.050^{* * * *} \\
(0.005)\end{array}$ & $\begin{array}{c}0.172^{* * * *} \\
(0.018)\end{array}$ \\
\hline \multicolumn{5}{|c|}{ Initially underskilled } \\
\hline Training & $\begin{array}{c}-0.006^{* * *} \\
(0.001)\end{array}$ & $\begin{array}{c}-0.035^{* * *} \\
(0.007)\end{array}$ & $\begin{array}{c}-0.038^{* * * *} \\
(0.006)\end{array}$ & $\begin{array}{c}0.079^{* * * *} \\
(0.014)\end{array}$ \\
\hline IL sometimes & $\begin{array}{l}-0.001 \\
(0.003)\end{array}$ & $\begin{array}{c}-0.002 \\
(0.014)\end{array}$ & $\begin{array}{l}-0.001 \\
(0.013)\end{array}$ & $\begin{array}{c}0.004 \\
(0.030)\end{array}$ \\
\hline IL usually & $\begin{array}{l}-0.004^{*} \\
(0.002)\end{array}$ & $\begin{array}{l}-0.023^{*} \\
(0.012)\end{array}$ & $\begin{array}{l}-0.022^{*} \\
(0.012)\end{array}$ & $\begin{array}{l}0.049^{*} \\
(0.028)\end{array}$ \\
\hline IL always & $\begin{array}{c}-0.008^{* * * *} \\
(0.003)\end{array}$ & $\begin{array}{c}-0.055^{* * *} \\
(0.016)\end{array}$ & $\begin{array}{c}-0.070^{* * * *} \\
(0.016)\end{array}$ & $\begin{array}{c}0.133^{* * * *} \\
(0.021)\end{array}$ \\
\hline \multicolumn{5}{|c|}{ Initially overskilled } \\
\hline Training & $\begin{array}{c}-0.021^{\text {**** }} \\
(0.002)\end{array}$ & $\begin{array}{c}-0.063^{* * *} \\
(0.006)\end{array}$ & $\begin{array}{c}-0.005^{* *} \\
(0.002)\end{array}$ & $\begin{array}{c}0.089^{* * * *} \\
(0.008)\end{array}$ \\
\hline IL sometimes & $\begin{array}{c}-0.023^{* *} \\
(0.009)\end{array}$ & $\begin{array}{c}-0.051^{* * * *} \\
(0.016)\end{array}$ & $\begin{array}{l}0.013^{*} \\
(0.007)\end{array}$ & $\begin{array}{c}0.061^{* * * *} \\
(0.012)\end{array}$ \\
\hline IL usually & $\begin{array}{c}-0.038^{* * *} \\
(0.010)\end{array}$ & $\begin{array}{c}-0.096^{* * *} \\
(0.017)\end{array}$ & $\begin{array}{l}0.010^{*} \\
(0.005)\end{array}$ & $\begin{array}{c}0.124^{* * * *} \\
(0.014)\end{array}$ \\
\hline IL always & $\begin{array}{c}-0.051^{* * * *} \\
(0.010)\end{array}$ & $\begin{array}{c}-0.145^{* * *} \\
(0.018)\end{array}$ & $\begin{array}{l}-0.010^{*} \\
(0.005)\end{array}$ & $\begin{array}{c}0.206^{* * * *} \\
(0.017)\end{array}$ \\
\hline
\end{tabular}

This table shows AMEs computed on the ordered probit specification (2) in Table A3 in the Appendix. The dependent variable skill change is measured by 11 ordinal categories from zero to 10 $(0=$ skills have worsened a lot, $5=$ skills have stayed the same, $10=$ skills have improved a lot $)$. AMEs on skill change are grouped into four categories: worsened (0-4), no or hardly any change (5-6), intermediate improvement (7-8), and high improvement (9-10). The AME for categorical variables is the discrete change from the base level. Standard errors clustered at country level are shown in parentheses. ${ }^{*} p<0.10,{ }^{* *} p<0.05,{ }^{* * *} p<0.01 . \mathrm{N}=37,285$.

Table 4. AMEs of work-related learning on workers' skill development between job-skill s (mis)match groups (Interaction effects)

\begin{tabular}{lcccc} 
Skill change & $\mathbf{0 - 4}$ & $\mathbf{5 - 6}$ & $\mathbf{7 - 8}$ & $\mathbf{9 - 1 0}$ \\
\hline Initially underskilled (well matched ref.) & & & \\
Training & $-0.009^{* * *}$ & $-0.050^{* * * *}$ & $-0.048^{* * *}$ & $0.107^{* * * *}$ \\
& $(0.001)$ & $(0.003)$ & $(0.004)$ & $(0.007)$ \\
IL sometimes & $-0.014^{* * *}$ & $-0.060^{* * *}$ & $-0.031^{* * *}$ & $0.105^{* * *}$ \\
& $(0.001)$ & $(0.004)$ & $(0.002)$ & $(0.006)$ \\
IL usually & $-0.006^{* * *}$ & $-0.044^{* * *}$ & $-0.059^{* * *}$ & $0.109^{* * * *}$ \\
& $(0.001)$ & $(0.004)$ & $(0.007)$ & $(0.011)$ \\
IL always & $-0.011^{* * *}$ & $-0.056^{* * *}$ & $-0.045^{* * *}$ & $0.112^{* * *}$ \\
& $(0.001)$ & $(0.005)$ & $(0.004)$ & $(0.009)$ \\
Initially overskilled (well matched ref.) & & & \\
Training & $0.011^{* * * *}$ & $0.040^{* * *}$ & $0.015^{* * *}$ & $-0.066^{* * *}$ \\
& $(0.001)$ & $(0.005)$ & $(0.002)$ & $(0.008)$ \\
IL sometimes & $0.019^{* * * *}$ & $0.054^{* * * *}$ & 0.002 & $-0.075^{* * *}$ \\
& $(0.003)$ & $(0.008)$ & $(0.001)$ & $(0.009)$ \\
IL usually & $0.007^{* * * *}$ & $0.033^{* * * *}$ & $0.022^{* * *}$ & $-0.062^{* * *}$ \\
& $(0.002)$ & $(0.007)$ & $(0.004)$ & $(0.008)$ \\
IL always & $0.010^{* * *}$ & $0.037^{* * *}$ & $0.011^{* * *}$ & $-0.058^{* * *}$ \\
& $(0.001)$ & $(0.005)$ & $(0.002)$ & $(0.006)$ \\
\hline
\end{tabular}

This table shows AMEs computed on the ordered probit specification (2) in Table A3 in the 
Appendix. The dependent variable skill change is measured by 11 ordinal categories from zero to 10 $(0=$ skills have worsened a lot, $5=$ skills have stayed the same, $10=$ skills have improved a lot $)$. AMEs on skill change are grouped into four categories: worsened (0-4), no or hardly any change (5-6), intermediate improvement (7-8), and high improvement (9-10). The AME for categorical variables is the discrete change from the base level. Standard errors clustered at country level are shown in parentheses. ${ }^{*} p<0.10,{ }^{* *} p<0.05,{ }^{* * *} p<0.01 . \mathrm{N}=37,285$.

Table 5. AMEs of work-related learning on workers' skill development including information on workers' learning and career attitudes

\begin{tabular}{|c|c|c|c|c|}
\hline Skill change & $0-4$ & $5-6$ & $7-8$ & 9-10 \\
\hline \multicolumn{5}{|c|}{ A. AMEs of work-related learning including learning motivation } \\
\hline \multirow[t]{2}{*}{ Training } & $-0.015^{* * *}$ & $-0.045^{* * * *}$ & $-0.018^{* * * *}$ & $0.078^{* * *}$ \\
\hline & $(0.001)$ & $(0.004)$ & $(0.002)$ & $(0.007)$ \\
\hline \multirow[t]{2}{*}{ IL sometimes } & $-0.018^{* * * *}$ & $-0.038^{* * * *}$ & 0.000 & $0.056^{* * * *}$ \\
\hline & $(0.005)$ & $(0.010)$ & $(0.004)$ & $(0.015)$ \\
\hline \multirow[t]{2}{*}{ IL usually } & $-0.027^{* * *}$ & $-0.068^{* * * *}$ & $-0.009^{* *}$ & $0.104^{* * * *}$ \\
\hline & $(0.005)$ & $(0.009)$ & $(0.004)$ & $(0.013)$ \\
\hline \multirow[t]{2}{*}{ IL always } & $-0.036^{* * * *}$ & $-0.103^{* * *}$ & $-0.034^{* * * *}$ & $0.173^{* * * *}$ \\
\hline & $(0.006)$ & $(0.010)$ & $(0.005)$ & $(0.015)$ \\
\hline \multirow[t]{2}{*}{ Underskilled } & $-0.013^{* * * *}$ & $-0.056^{* * * *}$ & $-0.044^{* * * *}$ & $0.113^{* * *}$ \\
\hline & $(0.001)$ & $(0.003)$ & $(0.003)$ & $(0.006)$ \\
\hline \multirow[t]{2}{*}{ overskilled } & $0.020^{* * *}$ & $0.051^{* * *}$ & $0.007^{* * * *}$ & $-0.078^{* * * *}$ \\
\hline & $(0.002)$ & $(0.005)$ & $(0.002)$ & $(0.007)$ \\
\hline \multirow[t]{2}{*}{ Learning motivation (std) } & $-0.013^{* * *}$ & $-0.041^{* * * *}$ & $-0.020^{* * * *}$ & $0.074^{* * * *}$ \\
\hline & $(0.001)$ & $(0.002)$ & $(0.001)$ & $(0.003)$ \\
\hline \multicolumn{5}{|c|}{ B. AMEs of work-related learning including importance of career development } \\
\hline \multirow[t]{2}{*}{ Training } & $-0.013^{* * *}$ & $-0.045^{* * *}$ & $-0.019^{* * * *}$ & $0.077^{* * *}$ \\
\hline & $(0.001)$ & $(0.004)$ & $(0.003)$ & $(0.007)$ \\
\hline \multirow[t]{2}{*}{ IL sometimes } & $-0.009^{* * *}$ & $-0.021^{* * *}$ & 0.003 & $0.027^{* *}$ \\
\hline & $(0.004)$ & $(0.010)$ & $(0.004)$ & $(0.013)$ \\
\hline \multirow[t]{2}{*}{ IL usually } & $-0.017^{* * * *}$ & $-0.048^{* * * *}$ & $-0.007^{*}$ & $0.072^{* * * *}$ \\
\hline & $(0.005)$ & $(0.012)$ & $(0.004)$ & $(0.018)$ \\
\hline \multirow[t]{2}{*}{ IL always } & $-0.026^{* * * *}$ & $-0.088^{* * * *}$ & $-0.037^{* * * *}$ & $0.151^{* * * *}$ \\
\hline & $(0.005)$ & $(0.012)$ & $(0.006)$ & $(0.020)$ \\
\hline \multirow[t]{2}{*}{ Underskilled } & $-0.013^{* * *}$ & $-0.058^{* * *}$ & $-0.042^{* * *}$ & $0.113^{* * * *}$ \\
\hline & $(0.001)$ & $(0.003)$ & $(0.003)$ & $(0.006)$ \\
\hline \multirow{2}{*}{ overskilled } & $0.013^{* * *}$ & $0.040^{* * *}$ & $0.007^{* * *}$ & $-0.060^{* * * *}$ \\
\hline & $(0.002)$ & $(0.006)$ & $(0.002)$ & $(0.008)$ \\
\hline \multirow{2}{*}{ Importance of career (std) } & $-0.007^{* * * *}$ & $-0.024^{* * * *}$ & $-0.012^{* * * *}$ & $0.043^{* * * *}$ \\
\hline & $(0.001)$ & $(0.002)$ & $(0.001)$ & $(0.003)$ \\
\hline
\end{tabular}

This table shows AMEs computed on an ordered probit specification similar to column (2) in Table A3 in the Appendix that includes a variable for learning attitude (Panel A) and a variable for the importance of career development opportunities to accept the job at the first place (in Panel B). The dependent variable skill change is measured by 11 ordinal categories from zero to $10(0=$ skills have worsened a lot, $5=$ skills have stayed the same, $10=$ skills have improved a lot). AMEs on skill change are grouped into four categories: worsened (0-4), no or hardly any change (5-6), intermediate improvement (7-8), and high improvement (9-10). The AME for categorical variables is the discrete change from the base level. Standard errors clustered at country level are shown in parentheses. ${ }^{*} p<0.10,{ }^{* *} p<0.05,{ }^{* * *} p<0.01$. N = 29,018 (Panel A). $\mathrm{N}=37,285$ (Panel B). 
Table 6. AMEs of work-related learning on workers' skill development (cat. 9-10)

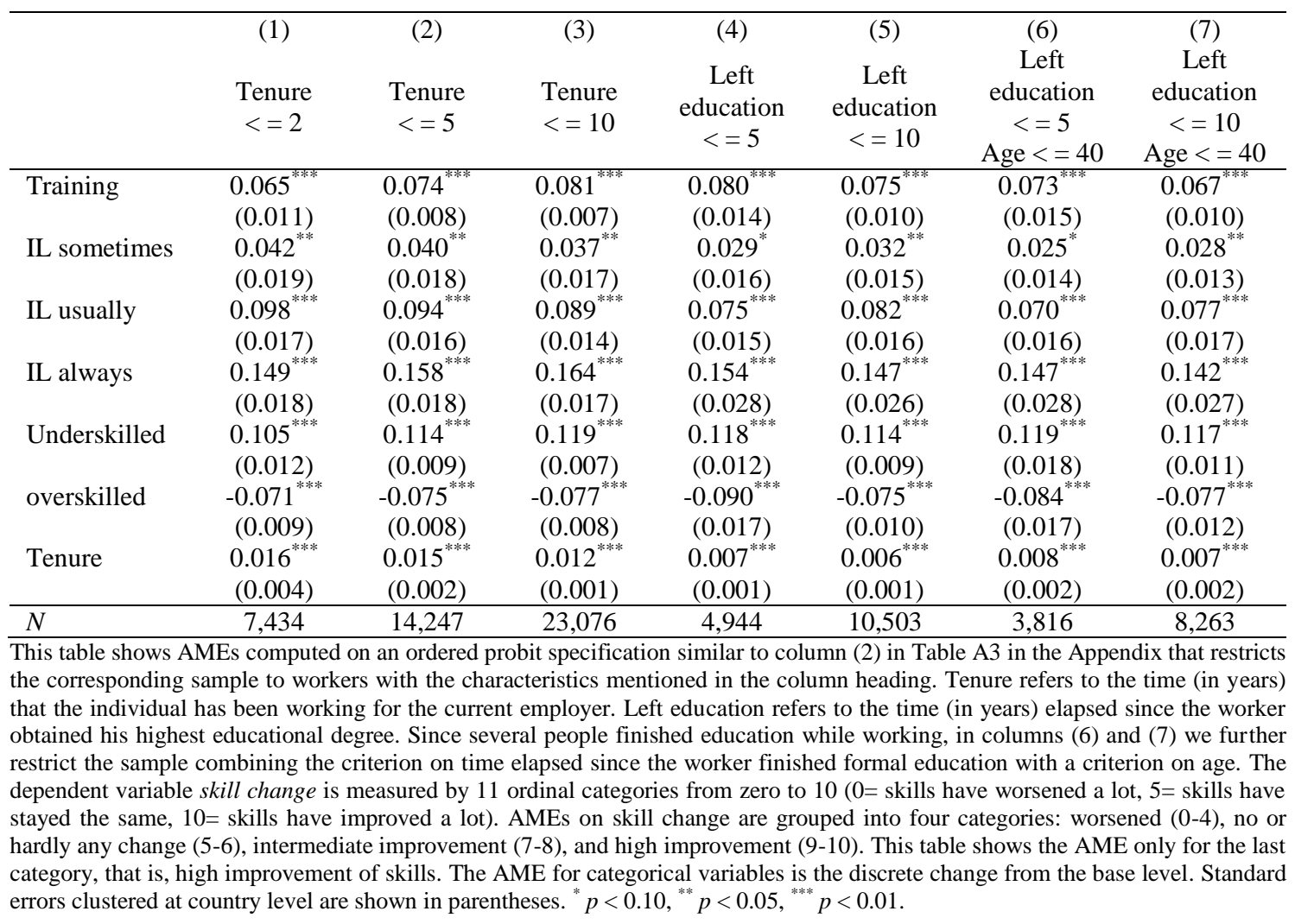


Table 7. AMEs of different types of training on workers' skill development

\begin{tabular}{|c|c|c|c|c|}
\hline Skill change & $0-4$ & $5-6$ & $7-8$ & $9-10$ \\
\hline \multicolumn{5}{|c|}{ A. AMEs within job-skill (mis)match groups } \\
\hline \multicolumn{5}{|l|}{ Initially well matched } \\
\hline \multirow[t]{2}{*}{ Training during working hours } & $-0.008^{* * * *}$ & $-0.028^{* * * *}$ & $-0.013^{* * * *}$ & $0.049^{* * * *}$ \\
\hline & $(0.001)$ & $(0.003)$ & $(0.002)$ & $(0.006)$ \\
\hline \multirow[t]{2}{*}{ Training outside working hours } & $-0.005^{* *}$ & $-0.008^{* *}$ & $-0.004^{*}$ & $0.017^{* * *}$ \\
\hline & $(0.002)$ & $(0.003)$ & $(0.002)$ & $(0.007)$ \\
\hline \multirow[t]{2}{*}{ Training paid by employer } & $-0.006^{* * * *}$ & $-0.031^{* * * *}$ & $-0.012^{* * * *}$ & $0.049^{* * * *}$ \\
\hline & $(0.001)$ & $(0.003)$ & $(0.002)$ & $(0.006)$ \\
\hline \multirow[t]{2}{*}{ Training paid by employee } & $-0.004^{*}$ & $-0.016^{* *}$ & $-0.007^{* *}$ & $0.027^{* *}$ \\
\hline & $(0.002)$ & $(0.007)$ & $(0.003)$ & $(0.012)$ \\
\hline \multicolumn{5}{|l|}{ Initially underskilled } \\
\hline \multirow[t]{2}{*}{ Training during working hours } & $-0.003^{* * *}$ & $-0.019^{* * *}$ & $-0.022^{* * * *}$ & $0.044^{* * * *}$ \\
\hline & $(0.001)$ & $(0.004)$ & $(0.004)$ & $(0.008)$ \\
\hline \multirow[t]{2}{*}{ Training outside working hours } & -0.001 & -0.005 & -0.005 & 0.011 \\
\hline & $(0.001)$ & $(0.005)$ & $(0.005)$ & $(0.012)$ \\
\hline \multirow[t]{2}{*}{ Training paid by employer } & $-0.003^{* * * *}$ & $-0.020^{* * * *}$ & $-0.022^{* * * *}$ & $0.045^{* * * *}$ \\
\hline & $(0.001)$ & $(0.004)$ & $(0.004)$ & $(0.009)$ \\
\hline \multirow[t]{2}{*}{ Training paid by employee } & $-0.008^{* *}$ & $-0.016^{* * *}$ & -0.002 & $0.026^{* *}$ \\
\hline & $(0.004)$ & $(0.007)$ & $(0.002)$ & $(0.013)$ \\
\hline \multicolumn{5}{|l|}{ Initially overskilled } \\
\hline \multirow[t]{2}{*}{ Training during working hours } & $-0.012^{* * * *}$ & $-0.035^{* * * *}$ & $-0.004^{* * * *}$ & $0.051^{* * * *}$ \\
\hline & $(0.002)$ & $(0.005)$ & $(0.001)$ & $(0.007)$ \\
\hline \multirow[t]{2}{*}{ Training outside working hours } & $-0.010^{* * * *}$ & $-0.033^{* * * *}$ & -0.002 & $0.045^{* * * *}$ \\
\hline & $(0.002)$ & $(0.007)$ & $(0.001)$ & $(0.010)$ \\
\hline \multirow[t]{2}{*}{ Training paid by employer } & $-0.013^{* * * *}$ & $-0.020^{* * *}$ & $-0.022^{* *}$ & $0.055^{* * * *}$ \\
\hline & $(0.001)$ & $(0.009)$ & $(0.010)$ & $(0.006)$ \\
\hline \multirow[t]{2}{*}{ Training paid by employee } & $-0.011^{* * *}$ & $-0.031^{* * * *}$ & $-0.004^{* * * *}$ & $0.046^{* * *}$ \\
\hline & $(0.001)$ & $(0.004)$ & $(0.001)$ & $(0.021)$ \\
\hline \multicolumn{5}{|c|}{ B. AMEs between job-skill (mis)match groups (well matched ref) } \\
\hline \multicolumn{5}{|l|}{ Initially underskilled } \\
\hline \multirow[t]{2}{*}{ Training during working hours } & $-0.009^{* * * *}$ & $-0.051^{* * * *}$ & $-0.044^{* * *}$ & $0.104^{* * * *}$ \\
\hline & $(0.001)$ & $(0.003)$ & $(0.003)$ & $(0.005)$ \\
\hline \multirow{2}{*}{ Training outside working hours } & -0.006 & $-0.022^{* *}$ & $-0.018^{* * * *}$ & $0.046^{* *}$ \\
\hline & $(0.005)$ & $(0.010)$ & $(0.003)$ & $(0.022)$ \\
\hline \multirow{2}{*}{ Training paid by employer } & $-0.008^{* * *}$ & $-0.053^{* * * *}$ & $-0.043^{* * *}$ & $0.104^{* * * *}$ \\
\hline & $(0.001)$ & $(0.004)$ & $(0.004)$ & $(0.008)$ \\
\hline \multirow[t]{2}{*}{ Training paid by employee } & $-0.010^{* * * *}$ & $-0.052^{* * * *}$ & $-0.037^{* * * *}$ & $0.099^{* * * *}$ \\
\hline & $(0.001)$ & $(0.006)$ & $(0.007)$ & $(0.014)$ \\
\hline \multicolumn{5}{|l|}{ Initially overskilled } \\
\hline Training during working hours & $0.009^{* * *}$ & $0.019^{* * * *}$ & $0.012^{* * *}$ & $-0.040^{* * *}$ \\
\hline & $(0.001)$ & $(0.004)$ & $(0.002)$ & $(0.008)$ \\
\hline Training outside working hours & 0.010 & 0.016 & $0.005^{*}$ & -0.031 \\
\hline & $(0.010)$ & $(0.010)$ & $(0.003)$ & $(0.025)$ \\
\hline Training paid by employer & $0.008^{* * *}$ & $0.025^{* * *}$ & $0.005^{*}$ & $-0.038^{* * * *}$ \\
\hline & $(0.003)$ & $(0.009)$ & $(0.002)$ & $(0.014)$ \\
\hline Training paid by employee & 0.009 & 0.014 & 0.000 & -0.023 \\
\hline & $(0.008)$ & $(0.019)$ & $(0.003)$ & $(0.022)$ \\
\hline
\end{tabular}

This table shows AMEs computed on an ordered probit regression similar to specification (2) in Table 2 that includes a categorical variable that distinguishes either between training during and outside regular working hours or between training financed by the employer and the employee. Workers who did not participate in any training are the reference category in both cases. The dependent variable skill change is measured by 11 ordinal categories from zero to $10(0=$ skills have worsened a lot, $5=$ skills have stayed the same, $10=$ skills have improved a lot). AMEs on skill change are grouped into four categories: worsened (0-4), no or hardly any change (5-6), intermediate improvement (7-8), and high improvement (9-10). The AME for categorical variables is the discrete change from the base level. Standard errors clustered at country level are shown in parentheses. ${ }^{*} p<0.10,{ }^{* *} p<0.05,{ }^{* * * *} p<0.01 . \mathrm{N}=36,477$. 
Table 8. AMEs of different types of informal learning on workers' skill improvement

\begin{tabular}{|c|c|c|c|c|c|}
\hline Skill change & 6 & 7 & 8 & 9 & 10 \\
\hline \multicolumn{6}{|c|}{ A. AMEs within job-skill (mis)match groups } \\
\hline \multicolumn{6}{|l|}{ Initially well matched } \\
\hline \multirow[t]{2}{*}{ IL from others } & $-0.009^{* * *}$ & $-0.011^{* * * *}$ & $-0.004^{* * *}$ & $0.006^{* * *}$ & $0.018^{* * *}$ \\
\hline & $(0.003)$ & $(0.0$ & & & \\
\hline \multirow[t]{2}{*}{ IL by trial and error } & $-0.008^{* * * *}$ & $-0.010^{* * * *}$ & $-0.003^{* * *}$ & $0.005^{* * *}$ & $0.016^{* * *}$ \\
\hline & $(0.003)$ & $(0.004)$ & $(0.001)$ & $(0.002)$ & $(0.006)$ \\
\hline \multirow[t]{2}{*}{ IL by self-study } & $-0.010^{* * * *}$ & $-0.011^{* * * *}$ & $-0.004^{* * *}$ & $0.008^{* * * *}$ & $0.017^{* * *}$ \\
\hline & $(0.004)$ & $(0.004)$ & $(0.001)$ & $(0.002)$ & $(0.006)$ \\
\hline \multicolumn{6}{|l|}{ Initially underskilled } \\
\hline \multirow[t]{2}{*}{ IL from others } & $-0.008^{* * *}$ & $-0.013^{* * *}$ & $-0.008^{* * *}$ & $0.004^{* * * *}$ & $0.025^{* * *}$ \\
\hline & $(0.003)$ & $(0.004)$ & $(0.002)$ & & \\
\hline \multirow[t]{2}{*}{ IL by trial and error } & -0.002 & -0.003 & -0.002 & 0.0 & 0.0 \\
\hline & $(0.002)$ & $(0.0$ & & & \\
\hline \multirow[t]{2}{*}{ IL by self-study } & $-0.013^{* * * *}$ & $-0.022^{* * * *}$ & $-0.014^{* * *}$ & $0.007^{* * *}$ & $0.042^{* * *}$ \\
\hline & $(0.003)$ & $(0.004)$ & & & \\
\hline \multicolumn{6}{|l|}{ Initially overskilled } \\
\hline \multirow[t]{2}{*}{ IL from others } & $-0.011^{* *}$ & $-0.011^{* *}$ & $-0.001^{* *}$ & $0.007^{* * *}$ & $0.016^{* *}$ \\
\hline & $(0.005)$ & $(0.005)$ & & & \\
\hline \multirow[t]{2}{*}{ IL by trial and error } & $-0.011^{* * *}$ & $-0.011^{* * *}$ & $-0.002^{* *}$ & $0.007^{* * *}$ & $0.017^{* * *}$ \\
\hline & $(0.005)$ & $(0.005)$ & $(0.001)$ & 3) & $(0.007)$ \\
\hline \multirow[t]{2}{*}{ IL by self-study } & -0.002 & -0.002 & -0.000 & 0.0 & 0.003 \\
\hline & $(0.004)$ & $(0.005)$ & $(0.001)$ & & \\
\hline \multicolumn{6}{|c|}{ B. AMEs between job-skill (mis)match groups (well matched ref.) } \\
\hline \multicolumn{6}{|l|}{ Initially underskilled } \\
\hline \multirow[t]{2}{*}{ IL from others } & $-0.022^{* * *}$ & $-0.028^{* * *}$ & $-0.020^{* * *}$ & $0.016^{* * *}$ & $0.054^{* * * *}$ \\
\hline & $(0.002)$ & $(0.003)$ & $(0$. & & $(0.006)$ \\
\hline \multirow[t]{2}{*}{ IL by trial and error } & $-0.029^{* * * *}$ & $-0.038^{* * * *}$ & $-0.015^{* * * *}$ & $0.017^{* * * *}$ & $0.065^{* * *}$ \\
\hline & $(0.004)$ & $(0.0$ & & & \\
\hline \multirow[t]{2}{*}{ IL by self-study } & $-0.032^{* * *}$ & $-0.047^{* * *}$ & $-0.024^{* * * *}$ & $0.018^{* * * *}$ & $0.085^{* * *}$ \\
\hline & $(0.003)$ & & & & \\
\hline \multicolumn{6}{|l|}{ Initially overskilled } \\
\hline \multirow[t]{2}{*}{ IL from others } & $0.007^{* * *}$ & $0.011^{* * *}$ & $0.003^{* * *}$ & $-0.009^{* * *}$ & $-0.012^{* * *}$ \\
\hline & & & & & \\
\hline \multirow[t]{2}{*}{ IL by trial and error } & $0.011^{* * * *}$ & $0.013^{* * * *}$ & $0.003^{* * * *}$ & $-0.007^{* * * *}$ & $-0.020^{* * * *}$ \\
\hline & $(0.003)$ & $(0.004)$ & $(0.001)$ & $(0.002)$ & $(0.006)$ \\
\hline \multirow[t]{2}{*}{ IL by self-study } & $0.013^{* * * *}$ & $0.015^{* * * *}$ & $0.004^{* * * *}$ & $-0.008^{* * * *}$ & $-0.024^{* * *}$ \\
\hline & $(0.004)$ & $(0.005)$ & $(0.001)$ & $(0.003)$ & $(0.007)$ \\
\hline \multicolumn{6}{|c|}{$\begin{array}{l}\text { This table shows AMEs computed on an ordered probit regression similar to specification (2) in } \\
\text { Table } 2 \text { that includes three dummy variables to account for the three different types of informal } \\
\text { learning. Since the question for the different types of informal learning was only asked to those } \\
\text { who reported a positive skill change, the dependent variable skill change in this regression only } \\
\text { takes values from six to } 10 \text {. The AME for categorical variables is the discrete change from the } \\
\text { base level. Standard errors clustered at country level are shown in parentheses. }{ }^{*} p<0.10,{ }^{* * *} p< \\
0.05,{ }^{* * *} p<0.01 \text {. } \mathrm{N}=31,385 \text {. }\end{array}$} \\
\hline
\end{tabular}


Table 9. Complementarity between training and informal learning (AMEs)

\begin{tabular}{lc} 
Training & Probit AMEs \\
\hline (IL never ref.) & $0.178^{* * *}$ \\
IL sometimes & $(0.019)$ \\
& $0.239^{* * *}$ \\
IL usually & $(0.019)$ \\
& $0.255^{* * *}$ \\
IL always & $(0.023)$
\end{tabular}

\begin{tabular}{lcccc}
\hline Informal learning & Never & Sometimes & Usually & Always \\
Oprobit AMEs & & & \\
\hline Training & $-0.019^{* * * *}$ & $-0.072^{* * *}$ & $0.026^{* * *}$ & $0.065^{* * *}$ \\
& $(0.003)$ & $(0.006)$ & $(0.003)$ & $(0.006)$ \\
\hline
\end{tabular}

All other controls are included. AMEs for categorical variables is the discrete change from the base level. Standard errors clustered at country level are shown in parentheses. ${ }^{*} p<$ $0.10, * * p<0.05, * * * p<0.01 . \mathrm{N}=37,187$.

Table 10. Conditional AMEs of training and informal learning on workers' skill development

\begin{tabular}{|c|c|c|c|c|}
\hline Skill change & $0-4$ & $5-6$ & 7-8 & $9-10$ \\
\hline \multicolumn{5}{|l|}{ A. Conditional AMEs } \\
\hline \multicolumn{5}{|l|}{ AME of Training } \\
\hline at IL never & $\begin{array}{c}-0.018^{* * * *} \\
(0.003)\end{array}$ & $\begin{array}{c}-0.051^{* * * *} \\
(0.004)\end{array}$ & $\begin{array}{l}-0.000 \\
(0.004)\end{array}$ & $\begin{array}{c}0.069^{* * * *} \\
(0.005)\end{array}$ \\
\hline at IL sometimes & $\begin{array}{c}-0.016^{* * * *} \\
(0.001)\end{array}$ & $\begin{array}{c}-0.053^{* * * *} \\
(0.004)\end{array}$ & $\begin{array}{c}-0.012^{* * * *} \\
(0.002)\end{array}$ & $\begin{array}{l}0.081^{* * * * *} \\
(0.006)\end{array}$ \\
\hline at IL usually & $\begin{array}{c}-0.012^{* * * *} \\
(0.001)\end{array}$ & $\begin{array}{c}-0.051^{* * * *} \\
(0.004)\end{array}$ & $\begin{array}{c}-0.025^{* * *} \\
(0.003)\end{array}$ & $\begin{array}{l}0.088^{* * * *} \\
(0.006)\end{array}$ \\
\hline at IL always & $\begin{array}{c}-0.009^{* * * *} \\
(0.001)\end{array}$ & $\begin{array}{c}-0.044^{* * * *} \\
(0.004)\end{array}$ & $\begin{array}{c}-0.042^{* * * *} \\
(0.004)\end{array}$ & $\begin{array}{c}0.095^{* * * *} \\
(0.007)\end{array}$ \\
\hline \multicolumn{5}{|l|}{ AME of IL sometimes } \\
\hline at Training $=0$ & $\begin{array}{c}-0.011^{* *} \\
(0.005)\end{array}$ & $\begin{array}{c}-0.024^{* * *} \\
(0.011)\end{array}$ & $\begin{array}{l}0.012^{* *} \\
(0.005)\end{array}$ & $\begin{array}{c}0.023^{*} \\
(0.011)\end{array}$ \\
\hline at Training $=1$ & $\begin{array}{l}-0.009^{* * *} \\
(0.004)\end{array}$ & $\begin{array}{l}-0.026^{* * *} \\
(0.011)\end{array}$ & $\begin{array}{l}-0.000 \\
(0.005)\end{array}$ & $\begin{array}{l}0.035^{* *} \\
(0.015)\end{array}$ \\
\hline $\begin{array}{l}\text { AME of IL usually } \\
\text { at Training }=0\end{array}$ & $\begin{array}{c}-0.023^{* * * *} \\
(0.006)\end{array}$ & $\begin{array}{c}-0.056^{* * *} \\
(0.012)\end{array}$ & $\begin{array}{c}0.005 \\
(0.004)\end{array}$ & $\begin{array}{l}0.074^{* * *} \\
(0.011)\end{array}$ \\
\hline at Training $=1$ & $\begin{array}{c}-0.017^{* * * *} \\
(0.004)\end{array}$ & $\begin{array}{c}-0.056^{* * * *} \\
(0.012)\end{array}$ & $\begin{array}{c}-0.020^{* * * *} \\
(0.005)\end{array}$ & $\begin{array}{l}0.093^{* * * *} \\
(0.012)\end{array}$ \\
\hline $\begin{array}{l}\text { AME of IL always } \\
\text { at Training=0 }\end{array}$ & $\begin{array}{c}-0.034^{* * * *} \\
(0.006)\end{array}$ & $\begin{array}{c}-0.104^{* * *} \\
(0.013)\end{array}$ & $\begin{array}{c}-0.017^{* * * *} \\
(0.005)\end{array}$ & $\begin{array}{l}0.155^{* * *} \\
(0.012)\end{array}$ \\
\hline at Training $=1$ & $\begin{array}{c}-0.025^{* * * *} \\
(0.004)\end{array}$ & $\begin{array}{c}-0.097^{* * * *} \\
(0.012)\end{array}$ & $\begin{array}{c}-0.059^{* * * *} \\
(0.007)\end{array}$ & $\begin{array}{c}0.181^{* * * *} \\
(0.014)\end{array}$ \\
\hline \multicolumn{5}{|c|}{ 2. Interaction effect (Training $=0$ and IL never ref.) } \\
\hline at Training $=1$ and IL always & $\begin{array}{c}-0.043^{* * * *} \\
(0.005)\end{array}$ & $\begin{array}{c}-0.148^{* * * *} \\
(0.014)\end{array}$ & $\begin{array}{c}-0.059^{* * * *} \\
(0.006)\end{array}$ & $\begin{array}{l}0.250^{* * *} \\
(0.018)\end{array}$ \\
\hline
\end{tabular}


Table 11. Conditional AMEs of work-related learning on workers' skill development within and between job-skill s (mis)match groups

\begin{tabular}{|c|c|c|c|c|}
\hline Skill change & $0-4$ & 5-6 & $7-8$ & $9-10$ \\
\hline \multicolumn{5}{|l|}{ Initially well matched } \\
\hline AME of Training at IL never & $\begin{array}{c}-0.014^{* * * *} \\
(0.003)\end{array}$ & $\begin{array}{c}-0.056^{* * * *} \\
(0.005)\end{array}$ & $\begin{array}{l}-0.003 \\
(0.005)\end{array}$ & $\begin{array}{c}0.073^{* * * *} \\
(0.006)\end{array}$ \\
\hline at IL always & $\begin{array}{c}-0.007^{* * * *} \\
(0.001)\end{array}$ & $\begin{array}{c}-0.045^{\text {**** }} \\
(0.004)\end{array}$ & $\begin{array}{c}-0.042^{* * *} \\
(0.004)\end{array}$ & $\begin{array}{l}0.094^{* * * *} \\
(0.007)\end{array}$ \\
\hline AME of IL always at Training $=0$ & $\begin{array}{c}-0.026^{* * *} \\
(0.006)\end{array}$ & $\begin{array}{c}-0.108^{* * *} \\
(0.016)\end{array}$ & $\begin{array}{c}-0.025^{* * *} \\
(0.004)\end{array}$ & $\begin{array}{c}0.159^{* * *} \\
(0.014)\end{array}$ \\
\hline \multirow[t]{2}{*}{ at Training $=1$} & $-0.019^{* * * *}$ & $-0.097^{* * * *}$ & $-0.064^{* * *}$ & $0.180^{* * * *}$ \\
\hline & $(0.004)$ & $(0.015)$ & $(0.007)$ & $(0.015)$ \\
\hline \multicolumn{5}{|c|}{ Interaction effect within well-matched workers (Training $=0$ and IL never ref.) } \\
\hline \multirow[t]{2}{*}{ Training = 1 and IL always } & $-0.033^{* * * *}$ & $-0.153^{* * * *}$ & $-0.067^{* * *}$ & $0.253^{* * *}$ \\
\hline & $(0.006)$ & $(0.017)$ & $(0.005)$ & $(0.021)$ \\
\hline \multicolumn{5}{|l|}{ Initially underskilled } \\
\hline \multirow[t]{2}{*}{ AME of Training at IL never } & $-0.007^{* * *}$ & $-0.039^{* * *}$ & $-0.033^{* * *}$ & $0.079^{* * * *}$ \\
\hline & $(0.002)$ & $(0.008)$ & $(0.007)$ & $(0.014)$ \\
\hline \multirow[t]{2}{*}{ at IL always } & $-0.003^{* * * *}$ & $-0.028^{* * * *}$ & $-0.049^{* * *}$ & $0.080^{* * * *}$ \\
\hline & $(0.001)$ & $(0.005)$ & $(0.009)$ & $(0.014)$ \\
\hline \multirow[t]{2}{*}{ AME of IL always at Training $=0$} & $-0.010^{* * *}$ & $-0.062^{* * *}$ & $-0.061^{* * *}$ & $0.133^{* * *}$ \\
\hline & $(0.003)_{* * *}$ & $(0.018)$ & $(0.013)$ & $(0.023)$ \\
\hline \multirow[t]{2}{*}{ at Training $=1$} & $-0.006^{* * * *}$ & $-0.051^{* * * *}$ & $-0.077^{* * *}$ & $0.134^{* * *}$ \\
\hline & $(0.002)$ & $(0.015)$ & $(0.018)$ & $(0.026)$ \\
\hline \multicolumn{5}{|c|}{ Interaction effect within underskilled workers (Training $=0$ and IL never ref.) } \\
\hline \multirow[t]{2}{*}{ Training $=1$ and IL always } & $-0.013^{* * *}$ & $-0.090^{* * * *}$ & $-0.110^{* * *}$ & $0.213^{* * *}$ \\
\hline & $(0.004)$ & $(0.018)$ & $(0.015)$ & $(0.031)$ \\
\hline \multicolumn{5}{|c|}{ Interaction effect between underskilled and well-matched workers (Training $=1$ and IL always ref.) } \\
\hline \multirow[t]{2}{*}{ Training $=1$ and IL always } & $-0.005^{* * *}$ & $-0.036^{* * *}$ & $-0.057^{* * *}$ & $0.098^{* * * *}$ \\
\hline & $(0.001)$ & $(0.004)$ & $(0.008)$ & $(0.012)$ \\
\hline \multicolumn{5}{|l|}{ Initially overskilled } \\
\hline \multirow[t]{2}{*}{ AME of Training at IL never } & $-0.036^{* * *}$ & $-0.066^{* * *}$ & $0.032^{* * *}$ & $0.070^{* * *}$ \\
\hline & $(0.006)$ & $(0.006)$ & $(0.009)$ & $(0.005)$ \\
\hline \multirow[t]{2}{*}{ at IL always } & $-0.012^{* * *}$ & $-0.057^{* * * *}$ & $-0.033^{* * *}$ & $0.102^{* * *}$ \\
\hline & $(0.001)$ & $(0.005)$ & $(0.005)$ & $(0.009)$ \\
\hline \multirow[t]{2}{*}{ AME of IL always at Training $=0$} & $-0.065^{* * *}$ & $-0.154^{* * *}$ & $0.032^{* *}$ & $0.187^{* * *}$ \\
\hline & $(0.013)$ & $(0.018)$ & $(0.008)$ & $(0.015)$ \\
\hline \multirow{2}{*}{ at Training $=1$} & $-0.041^{* * * *}$ & $-0.145^{* * * *}$ & $-0.033^{* * *}$ & $0.219^{* * * *}$ \\
\hline & $(0.008)$ & $(0.018)$ & $(0.008)$ & $(0.017)$ \\
\hline \multicolumn{5}{|c|}{ Interaction effect within overskilled workers (Training $=0$ and IL never ref.) } \\
\hline \multirow{2}{*}{ Training = 1 and IL always } & $-0.077^{* * * *}$ & $-0.211^{* * * *}$ & -0.001 & $0.289^{* * *}$ \\
\hline & $(0.014)$ & $(0.021)$ & $(0.014)$ & $(0.022)$ \\
\hline \multicolumn{5}{|c|}{ Interaction effect between overskilled and well-matched workers (Training $=1$ and IL always ref.) } \\
\hline \multirow[t]{2}{*}{ Training $=1$ and IL always } & $0.004^{* * *}$ & $0.028^{* * *}$ & $0.023^{* * *}$ & $-0.055^{* * * *}$ \\
\hline & $(0.001)$ & $(0.006)$ & $(0.005)$ & $(0.011)$ \\
\hline
\end{tabular}

This table shows conditional AMEs computed on an ordered probit regression similar to specification (2) in Table 2 that includes a third-way interaction term between the learning variables and the initial skill mismatch indicator. The dependent variable skill change is measured by 11 ordinal categories from zero to $10(0=$ skills have worsened a lot, $5=$ skills have stayed the same, $10=$ skills have improved a lot). AMEs on skill change are grouped into four categories: worsened (0-4), no or hardly any change (5-6), intermediate improvement (7-8), and high improvement (9-10). Standard errors clustered at country level are shown in parentheses. ${ }^{*} p<0.10,{ }^{* *} p<0.05,{ }^{* * *} p<0.01$. N $=37,285$. 
Figure 1. Skill development distribution by training participation

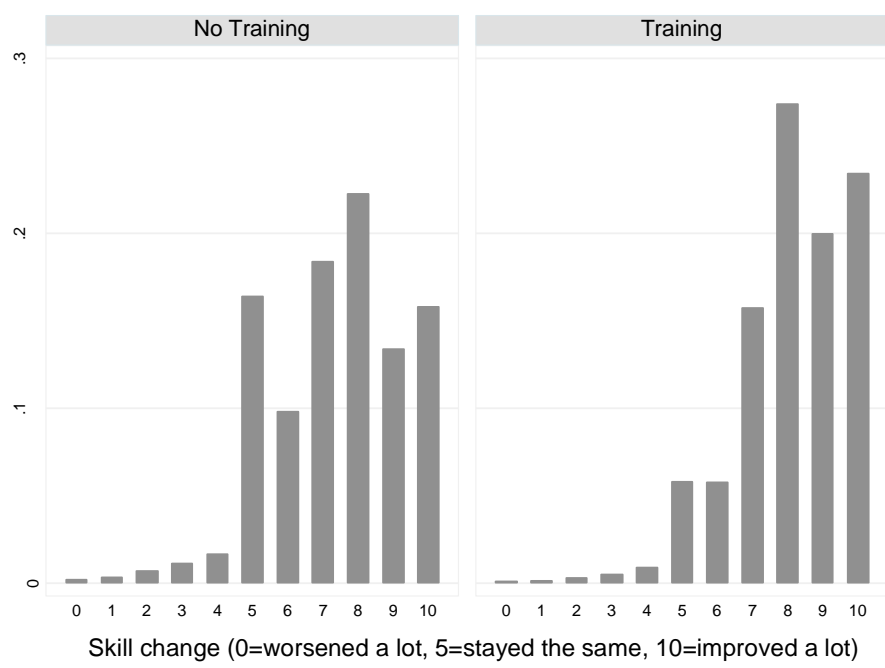

Figure 2. Skill development distribution by frequency of informal learning

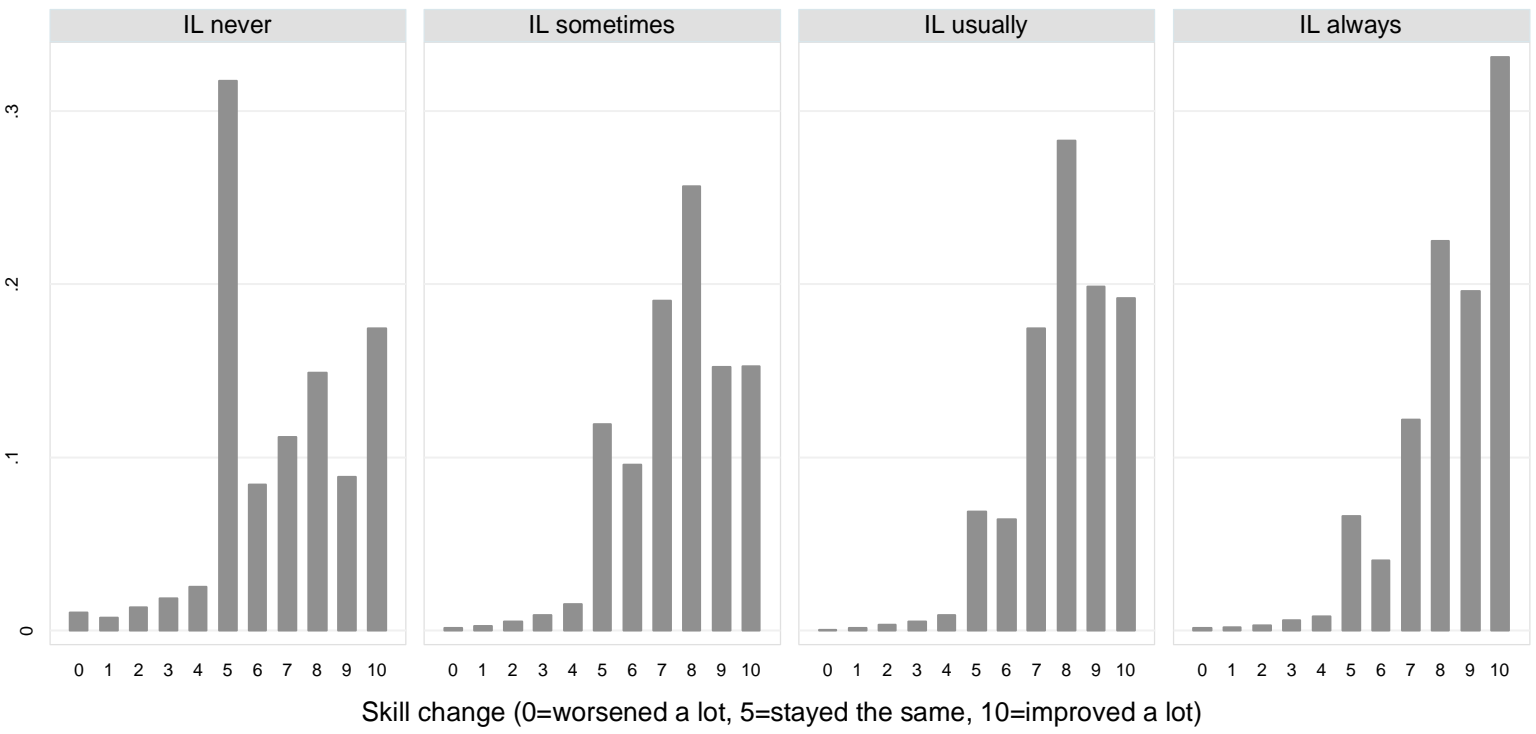

Figure 3. Skill development distribution by initial job-skill mismatch

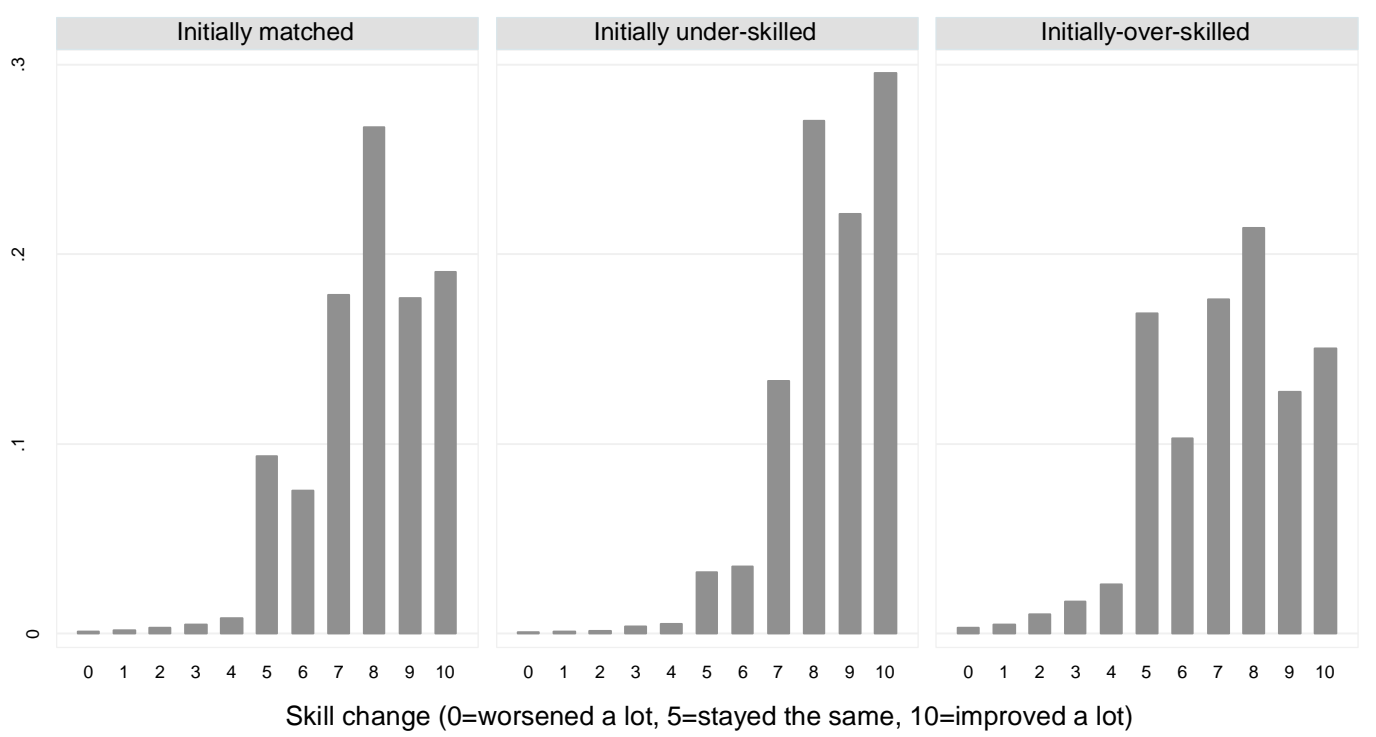


Figure 4. AMEs of work-related learning on workers' skill development (cat. 9-10) over years of tenure

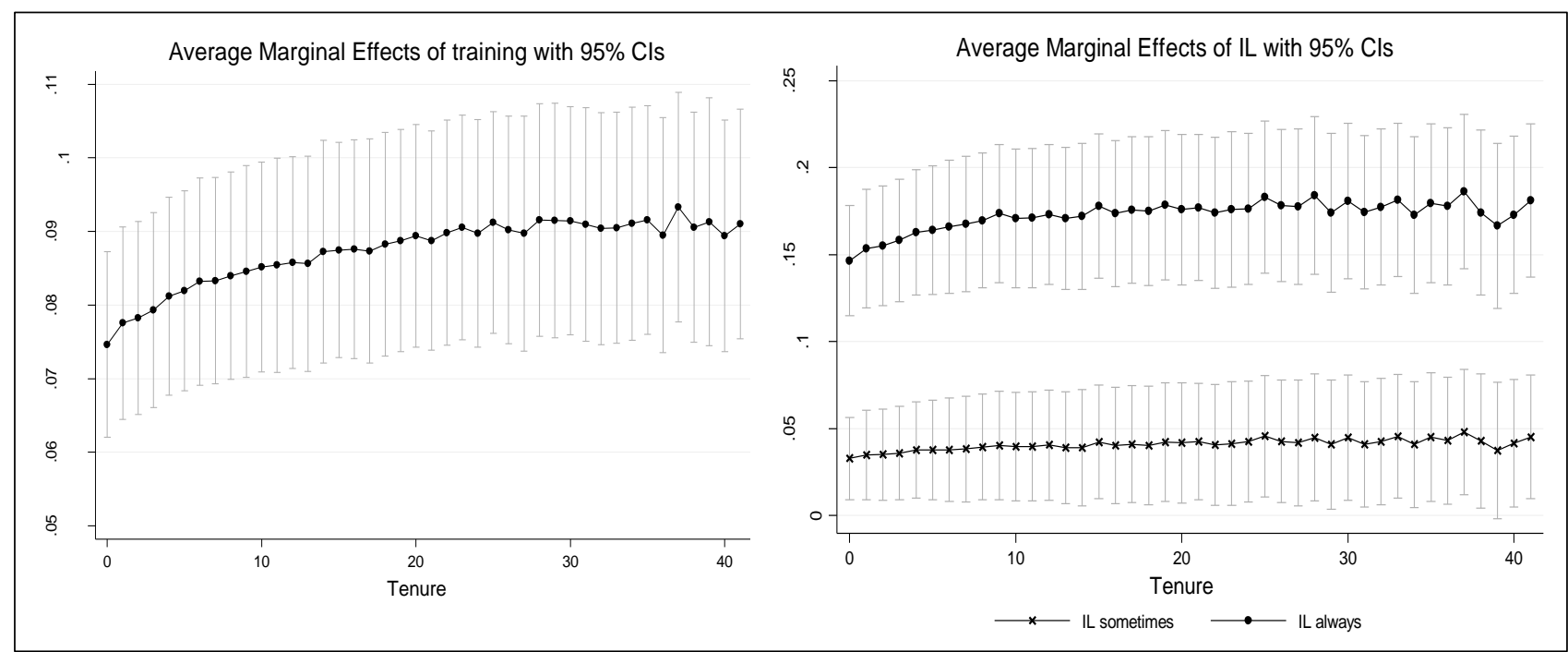

\section{APPENDIX}

Table A1. Distribution of the sample

\begin{tabular}{|c|c|c|c|c|c|}
\hline Country & Obs. & $\%$ Sample & $\begin{array}{c}\% \text { Initially } \\
\text { well matched }\end{array}$ & $\begin{array}{c}\% \text { Initially } \\
\text { underskilled }\end{array}$ & $\begin{array}{l}\text { \% Initially } \\
\text { overskilled }\end{array}$ \\
\hline United Kingdom & 2,830 & 7.6 & 41.8 & 24.0 & 34.2 \\
\hline Greece & 1,450 & 3.9 & 41.9 & 19.8 & 38.3 \\
\hline Slovakia & 835 & 2.2 & 41.9 & 36.1 & 22.0 \\
\hline Ireland & 749 & 2.0 & 42.7 & 26.7 & 30.6 \\
\hline Austria & 726 & 2.0 & 43.5 & 23.0 & 33.5 \\
\hline Finland & 1,578 & 4.2 & 43.9 & 29.0 & 27.2 \\
\hline Cyprus & 396 & 1.1 & 46.0 & 29.3 & 24.8 \\
\hline Czech Republic & 1,278 & 3.4 & 48.4 & 32.9 & 18.7 \\
\hline Estonia & 852 & 2.3 & 48.5 & 40.9 & 10.7 \\
\hline Lithuania & 820 & 2.2 & 49.9 & 39.2 & 11.0 \\
\hline France & 3,090 & 8.3 & 50.7 & 23.9 & 25.4 \\
\hline Poland & 3,175 & 8.5 & 51.1 & 21.5 & 27.3 \\
\hline Spain & 2,915 & 7.8 & 51.2 & 17.7 & 31.2 \\
\hline Germany & 2,937 & 7.9 & 51.8 & 19.1 & 29.2 \\
\hline Latvia & 808 & 2.2 & 52.4 & 37.0 & 10.6 \\
\hline Denmark & 694 & 1.9 & 52.5 & 24.1 & 23.5 \\
\hline Belgium & 1,003 & 2.7 & 52.6 & 20.2 & 27.1 \\
\hline Italy & 2,283 & 6.1 & 53.8 & 20.5 & 25.8 \\
\hline Hungary & 1,275 & 3.4 & 54.6 & 21.8 & 23.6 \\
\hline Bulgaria & 882 & 2.4 & 55.7 & 27.1 & 17.2 \\
\hline Croatia & 884 & 2.4 & 56.9 & 22.4 & 20.7 \\
\hline Netherlands & 820 & 2.2 & 57.1 & 20.2 & 22.7 \\
\hline Sweden & 742 & 2.0 & 57.3 & 19.3 & 23.5 \\
\hline Portugal & 1,276 & 3.4 & 57.6 & 24.1 & 18.3 \\
\hline Malta & 407 & 1.1 & 57.7 & 28.8 & 13.5 \\
\hline Romania & 1,303 & 3.5 & 59.6 & 25.6 & 14.8 \\
\hline Slovenia & 856 & 2.3 & 60.5 & 18.5 & 21.0 \\
\hline Luxembourg & 421 & 1.1 & 73.6 & 11.4 & 15.0 \\
\hline TOTAL & 37,285 & 100 & 50.94 & 23.92 & 25.14 \\
\hline
\end{tabular}


Table A2. Descriptive statistics

\begin{tabular}{|c|c|c|c|c|}
\hline & All & $\begin{array}{r}\text { Initially } \\
\text { well matched } \\
(51 \%)\end{array}$ & $\begin{array}{c}\text { Initially } \\
\text { underskilled } \\
(24 \%) \\
\end{array}$ & $\begin{array}{c}\begin{array}{c}\text { Initially } \\
\text { overskilled }\end{array} \\
(25 \%)\end{array}$ \\
\hline Training (during tenure) & 0.62 & 0.61 & 0.70 & 0.58 \\
\hline Training 12 months & 0.57 & 0.56 & 0.60 & 0.55 \\
\hline Training during working hours & 0.45 & 0.43 & 0.49 & 0.43 \\
\hline Training outside working hours & 0.22 & 0.21 & 0.19 & 0.24 \\
\hline Training paid by the employer & 0.69 & 0.69 & 0.71 & 0.66 \\
\hline Training paid by the employee & 0.12 & 0.11 & 0.10 & 0.16 \\
\hline IL never & 0.04 & 0.04 & 0.02 & 0.05 \\
\hline IL sometimes & 0.41 & 0.40 & 0.38 & 0.45 \\
\hline IL usually & 0.33 & 0.34 & 0.36 & 0.30 \\
\hline IL always & 0.22 & 0.22 & 0.23 & 0.20 \\
\hline IL from others* & 0.77 & 0.76 & 0.86 & 0.72 \\
\hline IL by trial and error* & 0.61 & 0.58 & 0.70 & 0.58 \\
\hline IL by self-study* & 0.56 & 0.52 & 0.63 & 0.55 \\
\hline Formal education (during tenure) & 0.14 & 0.13 & 0.17 & 0.11 \\
\hline \multicolumn{5}{|l|}{ Individual characteristics } \\
\hline Age $(24-65)$ s.d. $=9.8$ & 42.10 & 42.39 & 41.33 & 42.25 \\
\hline Female & 0.39 & 0.39 & 0.42 & 0.37 \\
\hline Low level of education & 0.12 & 0.13 & 0.12 & 0.10 \\
\hline Intermediate level of education & 0.41 & 0.43 & 0.42 & 0.38 \\
\hline High level of education & 0.47 & 0.44 & 0.47 & 0.52 \\
\hline Years of tenure $(0-41)$ s.d. $=9.3$ & 10.50 & 10.88 & 11.33 & 8.93 \\
\hline Permanent contract & 0.87 & 0.87 & 0.88 & 0.85 \\
\hline Fixed temporary contract & 0.10 & 0.10 & 0.09 & 0.12 \\
\hline Temporary agency contract & 0.01 & 0.01 & 0.01 & 0.01 \\
\hline No formal contract & 0.02 & 0.02 & 0.02 & 0.02 \\
\hline Telephone (interviewed) & 0.21 & 0.23 & 0.24 & 0.13 \\
\hline \multicolumn{5}{|l|}{ Industry } \\
\hline Agriculture & 0.02 & 0.02 & 0.02 & 0.02 \\
\hline Manufacturing & 0.19 & 0.19 & 0.21 & 0.18 \\
\hline Construction & 0.06 & 0.07 & 0.06 & 0.05 \\
\hline Sales and transportation & 0.20 & 0.19 & 0.17 & 0.23 \\
\hline Information and communication & 0.07 & 0.07 & 0.08 & 0.07 \\
\hline Financial and real state & 0.06 & 0.06 & 0.06 & 0.06 \\
\hline Professional and Tech & 0.07 & 0.07 & 0.08 & 0.06 \\
\hline Public administration & 0.25 & 0.26 & 0.25 & 0.25 \\
\hline Other services & 0.08 & 0.08 & 0.07 & 0.08 \\
\hline \multicolumn{5}{|l|}{ Occupation } \\
\hline Managers & 0.09 & 0.08 & 0.09 & 0.10 \\
\hline Professionals & 0.22 & 0.22 & 0.24 & 0.18 \\
\hline Technicians & 0.17 & 0.17 & 0.19 & 0.15 \\
\hline Service and sales workers & 0.12 & 0.12 & 0.11 & 0.14 \\
\hline Clerical support & 0.21 & 0.20 & 0.18 & 0.24 \\
\hline Skilled agricultural & 0.01 & 0.01 & 0.01 & 0.01 \\
\hline Building, crafts or related trades & 0.08 & 0.09 & 0.09 & 0.06 \\
\hline
\end{tabular}




\begin{tabular}{lcccc} 
Plant and machine operators & 0.07 & 0.07 & 0.07 & 0.08 \\
Elementary & 0.04 & 0.04 & 0.03 & 0.05 \\
Firm size & & & & \\
$1-9$ & 0.20 & 0.20 & 0.20 & 0.20 \\
$10-49$ & 0.28 & 0.28 & 0.29 & 0.27 \\
$50-99$ & 0.13 & 0.14 & 0.12 & 0.13 \\
$100-249$ & 0.13 & 0.13 & 0.13 & 0.14 \\
$250-499$ & 0.08 & 0.08 & 0.08 & 0.09 \\
$>500$ & 0.17 & 0.17 & 0.18 & 0.17 \\
Observations & 37,285 & 18,992 & 8,919 & 9,374 \\
\hline
\end{tabular}

For these variables we have fewer observations $(31,954)$. It is because the respective questions were only asked to respondents who reported a positive skill change in our dependent variable (i.e. above category 5 in the 0-10 scale).

Table A3. Ordered probit coefficients for skill development

\begin{tabular}{|c|c|c|}
\hline Skill change & $(1)$ & $(2)$ \\
\hline \multirow[t]{2}{*}{ Training } & $0.255^{* \cdots * *}$ & $0.251^{* * * *}$ \\
\hline & $(0.022)$ & $(0.022)$ \\
\hline \multirow[t]{2}{*}{ IL sometimes } & $0.145^{* *}$ & $0.122^{*}$ \\
\hline & $(0.056)$ & (0.064) \\
\hline \multirow[t]{2}{*}{ IL usually } & $0.300^{* * * *}$ & $0.258^{* * * *}$ \\
\hline & $(0.061)$ & $(0.069)$ \\
\hline \multirow[t]{2}{*}{ IL always } & $0.540^{* * * *}$ & $0.501^{* * * *}$ \\
\hline & $(0.067)$ & $(0.073)$ \\
\hline \multirow[t]{2}{*}{ Formal education } & $0.154^{* * * *}$ & $0.139^{* * * *}$ \\
\hline & $(0.021)$ & $(0.031)$ \\
\hline \multirow[t]{2}{*}{ Initially underskilled } & $0.304^{* * * *}$ & $0.461^{* * * *}$ \\
\hline & $(0.016)$ & $(0.084)$ \\
\hline \multirow[t]{2}{*}{ Initially overskilled } & $-0.218^{* * * *}$ & $-0.389^{* * * *}$ \\
\hline & $(0.026)$ & $(0.081)$ \\
\hline \multirow[t]{2}{*}{ Training \# Initially underskilled } & & -0.035 \\
\hline & & $(0.036)$ \\
\hline \multirow[t]{2}{*}{ Training \# Initially overskilled } & & $0.039^{*}$ \\
\hline & & $(0.021)$ \\
\hline \multirow[t]{2}{*}{ IL sometimes \# Initially underskilled } & & $-0.160^{* *}$ \\
\hline & & $(0.077)$ \\
\hline \multirow[t]{2}{*}{ IL sometimes \# Initially overskilled } & & 0.114 \\
\hline & & $(0.080)$ \\
\hline \multirow[t]{2}{*}{ IL usually \# Initially underskilled } & & $-0.151^{* *}$ \\
\hline & & $(0.075)$ \\
\hline \multirow[t]{2}{*}{ IL usually \# Initially overskilled } & & $0.217^{* * * *}$ \\
\hline & & $(0.080)$ \\
\hline \multirow[t]{2}{*}{ IL always \# Initially underskilled } & & $-0.170^{* *}$ \\
\hline & & $(0.081)$ \\
\hline \multirow{2}{*}{ IL always \# Initially overskilled } & & $0.218^{* *}$ \\
\hline & & $(0.091)$ \\
\hline \multirow[t]{2}{*}{ Formal education \# Initially underskilled } & & -0.024 \\
\hline & & $(0.033)$ \\
\hline \multirow[t]{2}{*}{ Formal education \# Initially overskilled } & & $0.103^{* *}$ \\
\hline & & $(0.044)$ \\
\hline \multirow[t]{2}{*}{ Age } & $-0.007^{* * * *}$ & $-0.007^{* * * *}$ \\
\hline & $(0.001)$ & $(0.001)$ \\
\hline \multirow[t]{2}{*}{ Female } & $0.209^{* * * *}$ & $0.209^{* * * *}$ \\
\hline & $(0.018)$ & $(0.018)$ \\
\hline \multirow{2}{*}{ Intermediate level of education } & $-0.077^{* * * *}$ & $-0.073^{* * * *}$ \\
\hline & $(0.025)$ & $(0.025)$ \\
\hline \multirow{2}{*}{ High level of education } & $-0.213^{* * * *}$ & $-0.209^{* * * *}$ \\
\hline & $(0.029)$ & $(0.030)$ \\
\hline \multirow[t]{2}{*}{ Years of tenure } & $0.016^{* * * *}$ & $0.016^{* * * *}$ \\
\hline & $(0.001)$ & $(0.001)$ \\
\hline
\end{tabular}




\begin{tabular}{lcc} 
Other controls & $y e s$ & $y e s$ \\
\hline cut1 & $-2.598^{* * * * *}(0.084)$ & $-2.635^{* * * *}(0.088)$ \\
cut2 & $-2.256^{* * * *}(0.076)$ & $-2.292^{* * * *}(0.081)$ \\
cut3 & $-1.939^{* * * *}(0.073)$ & $-1.975^{* * * *}(0.078)$ \\
cut4 & $-1.658^{* * * *}(0.071)$ & $-1.694^{* * * *}(0.076)$ \\
cut5 & $-1.392^{* * * *}(0.070)$ & $-1.427^{* * * *}(0.076)$ \\
cut6 & $-0.484^{* * * *}(0.069)$ & $-0.517^{* * * *}(0.075)$ \\
cut7 & $-0.142^{* * *}(0.068)$ & $-0.155^{* * *}(0.075)$ \\
cut8 & $0.476^{* * * *}(0.069)$ & $0.444^{* * * *}(0.074)$ \\
cut10 & $1.222^{* * *}(0.070)$ & $1.191^{* * *}(0.075)$ \\
\hline Pseudo R2 & $1.801^{* * * *}(0.070)$ & $1.769^{* * * *}(0.075)$ \\
BIC-stat $(27)$ & 0.0701 & 0.0709 \\
LR chi $^{2}(10)$ & $127,204.9$ & $127,147.8$ \\
\hline Specifica & & $37.13(0.0001)$ \\
\hline
\end{tabular}

Specification (1) gives the coefficients of the regression without interacting the learning variables and the workers' skill mismatch status, and specification (2) includes these interactions. The dependent variable skill change is measured from categories zero to $10(0=$ skills have worsened a lot, $5=$ skills have stayed the same, $10=$ skills have improved a lot). Other controls include dummies for changes in job-position and/or task content, the working process and the need of learning new things since the start of the job as well as dummies for type of contract, occupation, industry, firm size, country and survey answered by phone. Standard errors clustered at country level are shown in parentheses. ${ }^{*} p<0.10,{ }^{* *} p<0.05,{ }^{* * *} p<0.01 . \mathrm{N}=37,285$.

Table A4. Estimations of training and informal learning participation

\begin{tabular}{|c|c|c|c|}
\hline & $\begin{array}{c}(1) \\
\text { Probit AME } \\
\text { Training }\end{array}$ & $\begin{array}{c}(2) \\
\text { Probit AME } \\
\text { IL }\end{array}$ & $\begin{array}{c}\text { (4) } \\
\text { OLS } \\
\text { IL intensity }\end{array}$ \\
\hline Initially underskilled & 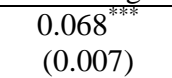 & $\begin{array}{c}0.048^{* * * *} \\
(0.004)\end{array}$ & $\begin{array}{l}0.055^{* * *} \\
(0.012)\end{array}$ \\
\hline Initially overskilled & $\begin{array}{c}-0.014^{* * * *} \\
(0.005)\end{array}$ & $\begin{array}{c}-0.016^{* * * *} \\
(0.003)\end{array}$ & $\begin{array}{c}-0.094^{* * *} \\
(0.017)\end{array}$ \\
\hline Age & $\begin{array}{c}-0.005^{* * *} \\
(0.002)\end{array}$ & $\begin{array}{c}-0.001^{\text {*** }} \\
(0.004)\end{array}$ & $\begin{array}{c}-0.010^{* * *} \\
(0.004)\end{array}$ \\
\hline $\operatorname{Age}^{2} * 100$ & $\begin{array}{l}0.007^{* * *} \\
(0.003)\end{array}$ & $\begin{array}{l}0.003^{* * *} \\
(0.001)\end{array}$ & $\begin{array}{l}0.007^{* * *} \\
(0.003)\end{array}$ \\
\hline Female & $\begin{array}{l}-0.007 \\
(0.008)\end{array}$ & $\begin{array}{c}0.001 \\
(0.004)\end{array}$ & $\begin{array}{l}-0.017 \\
(0.016)\end{array}$ \\
\hline Intermediate level of education & $\begin{array}{c}0.051^{\text {**** }} \\
(0.012)\end{array}$ & $\begin{array}{c}0.008 \\
(0.006)\end{array}$ & $\begin{array}{l}0.077^{* * *} \\
(0.036)\end{array}$ \\
\hline High level of education & $\begin{array}{c}0.089^{* * * * *} \\
(0.013)\end{array}$ & $\begin{array}{c}0.020^{* * * *} \\
(0.006)\end{array}$ & $\begin{array}{c}0.124^{* * * *} \\
(0.036)\end{array}$ \\
\hline Years of tenure & $\begin{array}{c}0.009^{* * * *} \\
(0.000)\end{array}$ & $\begin{array}{c}-0.001^{* * * *} \\
(0.000)\end{array}$ & $\begin{array}{c}-0.002^{* * *} \\
(0.001)\end{array}$ \\
\hline Temporary contract & $\begin{array}{c}-0.083^{* * * *} \\
(0.009)\end{array}$ & $\begin{array}{l}0.013^{*} \\
(0.008)\end{array}$ & $\begin{array}{c}0.082^{* * * *} \\
(0.016)\end{array}$ \\
\hline Agency contract & $\begin{array}{c}-0.154^{* * * *} \\
(0.039)\end{array}$ & $\begin{array}{c}0.034^{* * * *} \\
(0.012)\end{array}$ & $\begin{array}{l}0.122^{* * *} \\
(0.056)\end{array}$ \\
\hline No formal contract & $\begin{array}{c}-0.166^{* * * *} \\
(0.023)\end{array}$ & $\begin{array}{c}0.001 \\
(0.008)\end{array}$ & $\begin{array}{c}0.035 \\
(0.046)\end{array}$ \\
\hline Learning attitude (std) & $\begin{array}{c}0.022^{* * * * *} \\
(0.003)\end{array}$ & $\begin{array}{l}-0.002 \\
(0.002)\end{array}$ & $\begin{array}{c}0.147^{* * *} \\
(0.015)\end{array}$ \\
\hline Other controls & yes & yes & yes \\
\hline
\end{tabular}

Columns (1) and (2) in this table show AMEs computed based on probit regressions. Column (3) reports OLS coefficients. Other controls include occupation, industry, firm size and country dummies. The AME for categorical variables is the discrete change from the base level. Standard errors clustered at country level are shown in parentheses. ${ }^{*} p<0.10,{ }^{* *} p<0.05,{ }^{* * *} p<0.01 . \mathrm{N}=37,285$. 
Table A5. AMEs of work-related learning on workers' skill development

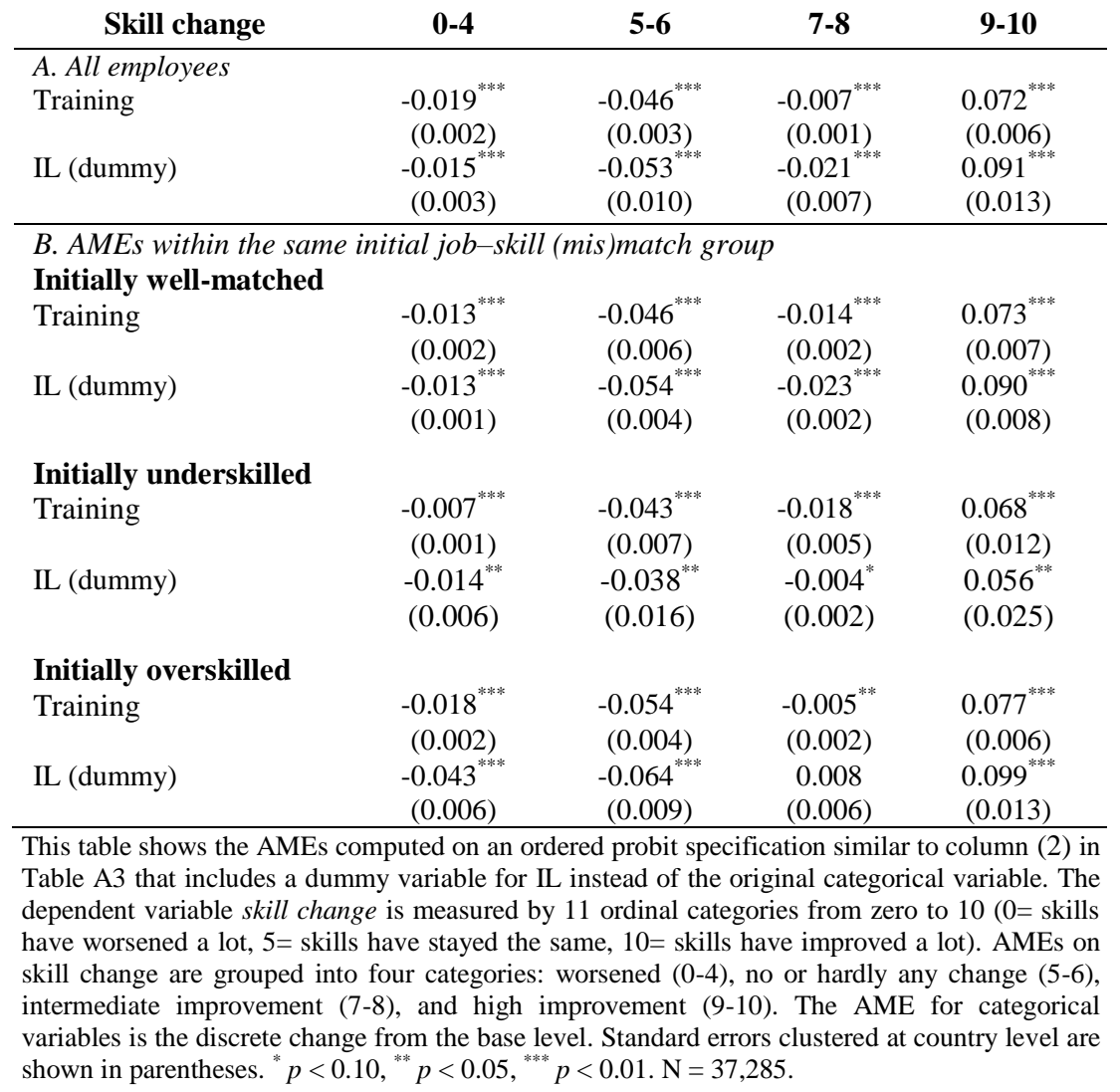

Table A6. Training (probit) estimations including informal learning as explanatory variable

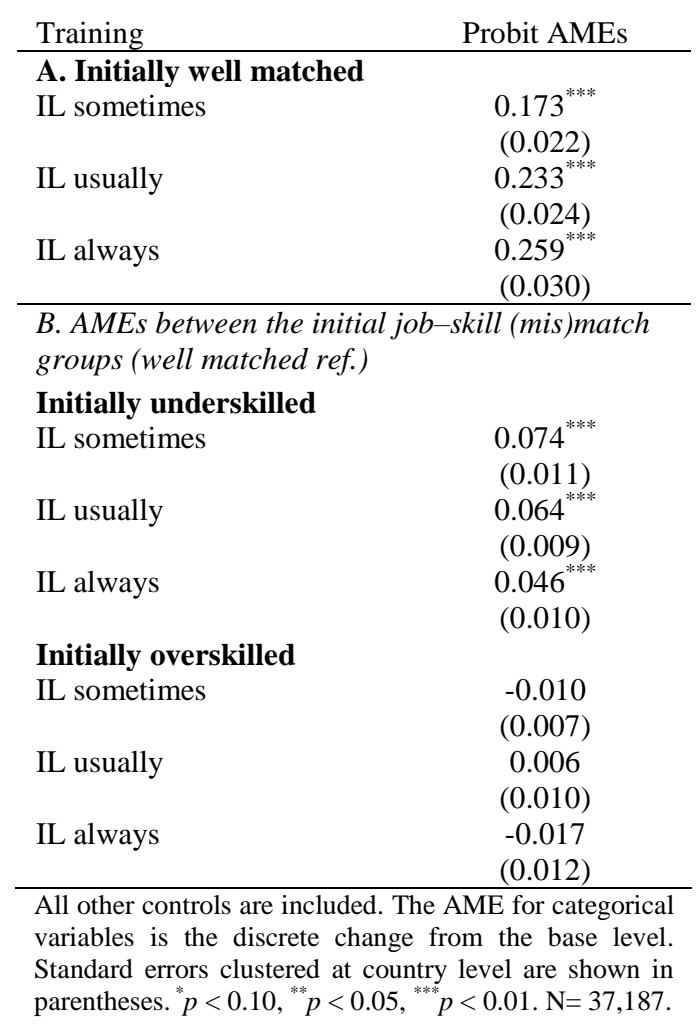


Table A7. Informal learning (oprobit) estimations including training as explanatory variable

\begin{tabular}{|c|c|c|c|c|}
\hline Informal learning & Never & Sometimes & Usually & Always \\
\hline $\begin{array}{l}\text { A. Initially well matched } \\
\text { Training }\end{array}$ & $\begin{array}{c}-0.017^{* * *} \\
(0.003)\end{array}$ & $\begin{array}{c}-0.072^{* * *} \\
(0.008)\end{array}$ & $\begin{array}{l}0.024^{* * * *} \\
(0.003)\end{array}$ & $\begin{array}{c}0.065^{* * *} \\
(0.007)\end{array}$ \\
\hline \multicolumn{5}{|c|}{ B. AME between the initial job-skill (mis)match groups (well matched ref.) } \\
\hline $\begin{array}{l}\text { Initially underskilled } \\
\text { Training }\end{array}$ & $\begin{array}{l}-0.002 \\
(0.001)\end{array}$ & $\begin{array}{l}-0.008 \\
(0.006)\end{array}$ & $\begin{array}{c}0.002 \\
(0.001)\end{array}$ & $\begin{array}{c}0.007 \\
(0.006)\end{array}$ \\
\hline $\begin{array}{l}\text { Initially overskilled } \\
\text { Training }\end{array}$ & $\begin{array}{l}0.005^{* * *} \\
(0.001)\end{array}$ & $\begin{array}{l}0.026^{* * * *} \\
(0.007)\end{array}$ & $\begin{array}{c}-0.006^{* * *} \\
(0.002)\end{array}$ & $\begin{array}{c}-0.024^{* * *} \\
(0.007)\end{array}$ \\
\hline
\end{tabular}

${ }^{* * *} p<0.01 . \mathrm{N}=37,187$.

Figure A1. AMEs of work-related learning on workers' skill development (cat. 9-10) within job-skill (mis)match groups over years of tenure

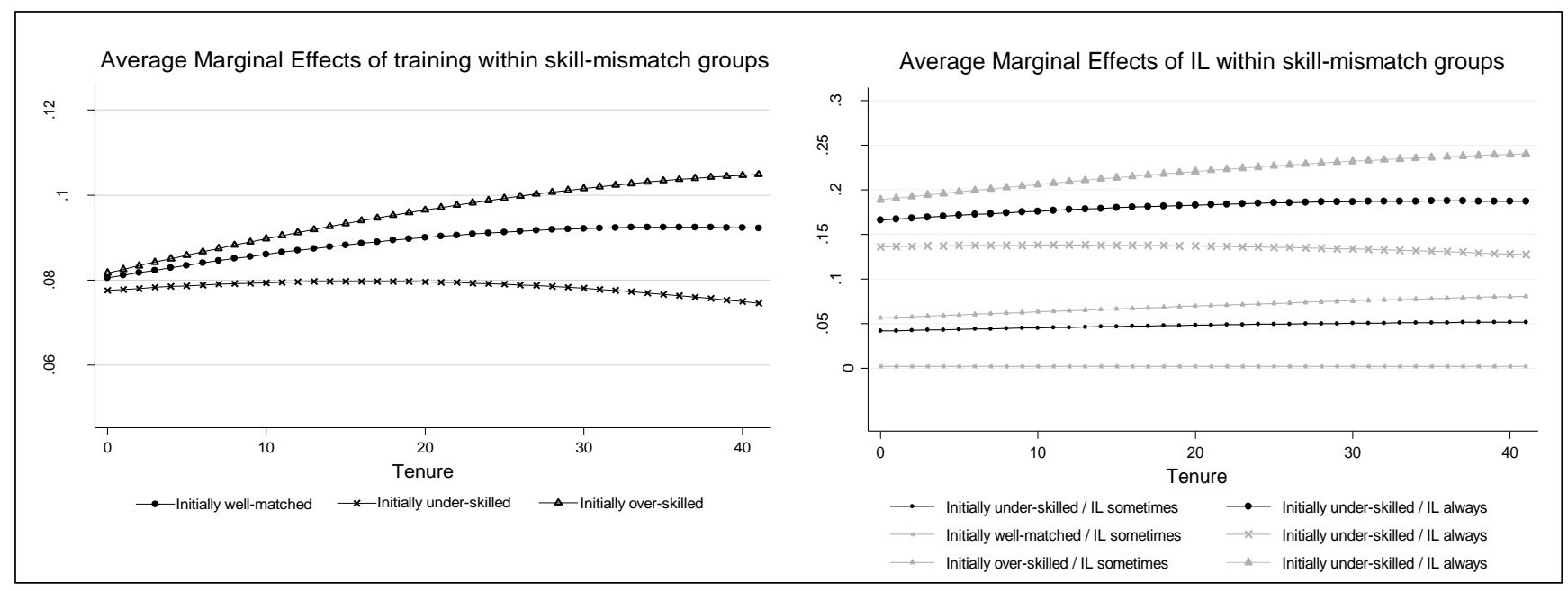

Figure A2. AMEs of work-related learning on workers' skill development (cat. 9-10) between job-skill (mis)match groups over years of tenure

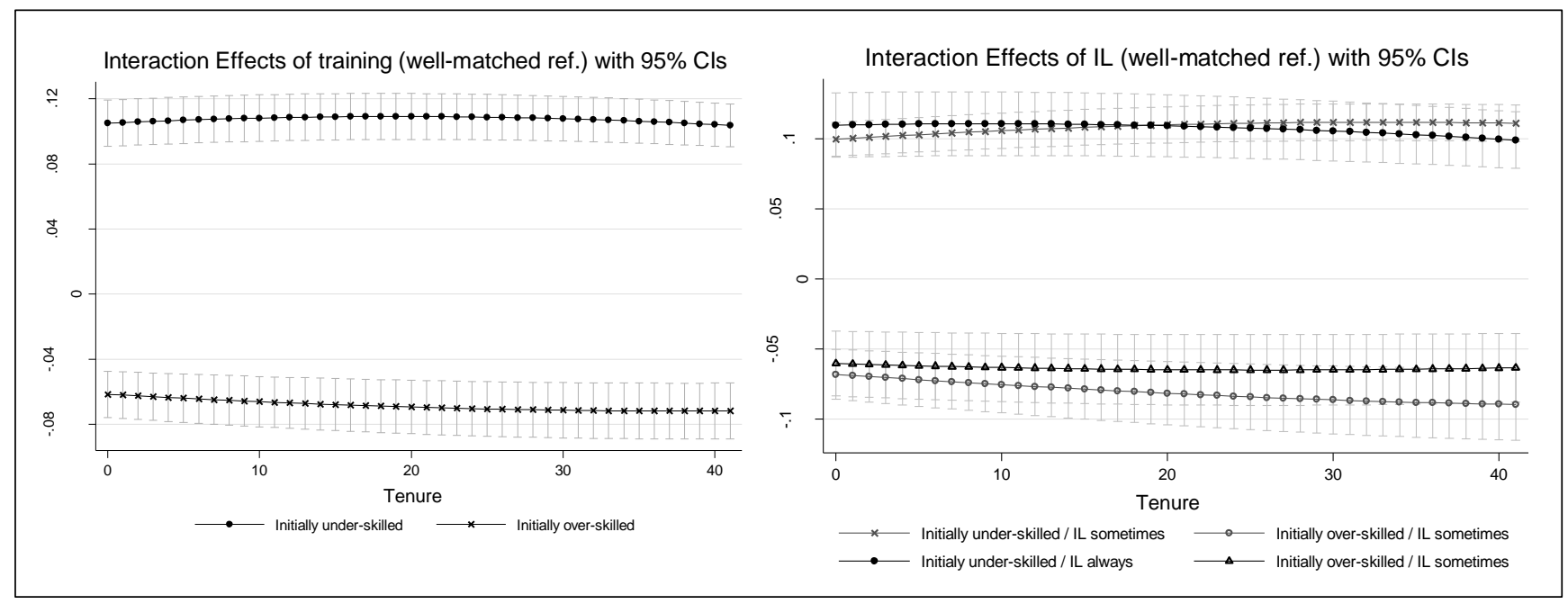

